\title{
ANAEROBIC-AEROBIC TREATMENT OF SWINE WASTEWATER IN UASB AND BATCH REACTORS IN SERIES
}

\section{ESTEVÃO URBINATI ${ }^{1}$, ROBERTO ALVES DE OLIVEIRA ${ }^{2}$}

\begin{abstract}
In this work it was evaluated the performance of two systems of swine wastewater treatment consisting of two-stage upflow anaerobic sludge blanket (UASB) reactors, with and without post-treatment in sequencing batch reactor (SBR), fed continuously, with aerobic phase. The UASB reactors in the first stage had $908 \mathrm{~L}$ in the sets I and II, and in the second stage 350 and $188 \mathrm{~L}$, respectively. In the set II the post-treatment was performed in a SBR of 3,000 L. The hydraulic detention times in the anaerobic treatment systems were 100, 75 and $58 \mathrm{~h}$ in the set I; 87, 65 and $51 \mathrm{~h}$ in the set II; and 240 and $180 \mathrm{~h}$ in the SBR. The volumetric organic load applied in the first stage UASB reactors ranged from 6.9 to $12.6 \mathrm{~g}$ total COD $(\mathrm{L} \mathrm{d})^{-1}$ in the set I and 7.5 to $9.8 \mathrm{~g}$ total COD $(\mathrm{L} \mathrm{d})^{-1}$ in the set II. The average removal efficiencies of total COD, total phosphorus $\left(\mathrm{P}_{\text {total }}\right)$, and Kjeldahl and organic nitrogen $\left(\mathrm{KN}\right.$ and $\left.\mathrm{N}_{\mathrm{org}}\right)$ in the anaerobic treatment systems were similar and reached maximum values of $97 \%, 64 \%, 68 \%$, and $98 \%$. In the SBR, the removal efficiencies of total COD and thermotolerant coliforms were up to 62 and $92 \%$ resulting, respectively, in effluent concentrations of $135 \mathrm{mg} \mathrm{L}^{-1}$ and $2 \times 10^{4} \mathrm{MPN}(100 \mathrm{~mL})^{-1}$. For $\mathrm{P}_{\text {total }}$, total nitrogen (TN) and $\mathrm{N}_{\text {org }}$, the average removal efficiencies in the SBR were up to 58, 25 and 73\%, respectively.
\end{abstract}

KEYWORDS: coliforms, methane, two-stage anaerobic reactors, nutrients removal, combined treatment.

\section{TRATAMENTO ANAERÓBIO-AERÓBIO DE ÁGUAS RESIDUÁRIAS DE SUINOCULTURA COM REATORES UASB E BATELADA EM SÉRIE}

RESUMO: O desempenho de dois sistemas de tratamento de águas residuárias de suinocultura com reatores anaeróbios de fluxo ascendente com manta de lodo (UASB), em dois estágios, foi avaliado com e sem pós-tratamento em reator operado em batelada sequencial alimentada (RBS), com etapa aeróbia. Os reatores UASB do primeiro estágio possuíam 908 L nos conjuntos I e II, e no segundo estágio, 350 e $188 \mathrm{~L}$, respectivamente. No conjunto II foi realizado o pós-tratamento em RBS de 3000 L. Os tempos de detenção hidráulica nos sistemas de tratamento foram de $100 ; 75$ e 58 h no conjunto I; de 87; 65 e 51 h no conjunto II, e de 240 e 180 h no RBS. As cargas orgânicas volumétricas nos reatores UASB do primeiro estágio variaram de 6,9 a 12,6 g DQOtotal $(\mathrm{L} \mathrm{d})^{-1}$ no conjunto I, e de 7,5 a 9,8 g DQOtotal ( $\mathrm{L} \mathrm{d})^{-1}$ no conjunto II. As eficiências médias de remoção de DQOtotal, fósforo total (Ptotal), nitrogênio Kjeldahl (NK) e nitrogênio orgânico (Norg.) nos sistemas de tratamento anaeróbio atingiram valores máximos de 97; 64; 68 e $98 \%$, respectivamente. No RBS, as eficiências de remoção de DQOtotal e coliformes termotolerantes foram de até 62 e $92 \%$, reduzindo para $135 \mathrm{mg} \mathrm{L}^{-1}$ e $2 \times 10^{4} \mathrm{NMP}(100 \mathrm{~mL})^{-1}$, respectivamente, os valores médios no efluente. Para o Ptotal, nitrogênio total (NT) e Norg, as eficiências de remoção no RBS foram de até $58 ; 25$ e $73 \%$, respectivamente.

PALAVRAS-CHAVE: coliformes, metano, reatores anaeróbios em dois estágios, remoção de nutrientes, tratamento combinado.

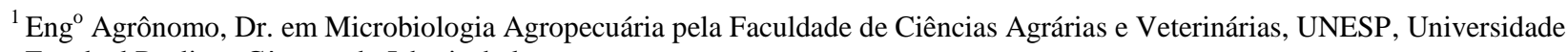
Estadual Paulista, Câmpus de Jaboticabal

${ }^{2}$ Eng $^{\circ}$ Agrônomo e Tecnólogo em Construção Civil; Mestre em Agronomia pela UNESP, Câmpus de Jaboticabal; Doutor em Hidráulica e Saneamento pela EESC-USP; Prof. Assist. Dr., Faculdade de Ciências Agrárias e Veterinárias, UNESP, Câmpus de Jaboticabal, Departamento de Engenharia Rural, Fone (0XX16)32097281, raoder@fcav.unesp.br 


\section{INTRODUCTION}

Brazilian hog raising has been undergoing considerable changes since the last decade due to its increasing production scale. Improvements in the production process increased the rate of productivity through the use of high densities of animals, but created a major environmental problem with the waste generated, and improper disposal practices of waste. Swine waste is characterized by high concentrations of organic material, nutrients and pathogens, which prolonged application in soil and bodies of water can cause problems such as eutrophication, contamination of soil and water with fecal microorganisms and release of methane and other undesirable gases to the atmosphere (MIRANDA, 2007; KUNZ et al., 2009).

The treatment in upflow anaerobic sludge blanket (UASB) is an attractive alternative, which has advantages such as low sludge production, small area of installation and low power consumption (FORESTI et al., 2006). Several authors attest to the viability of this technology for the treatment of swine wastewater. Among them, SONG et al. (2010) operated UASB 35,000 L at temperature of $35^{\circ} \mathrm{C}$, applying hydraulic detention time (HDT) decreasing from 7.0 to $3.5 \mathrm{~d}$ with increasing the volumetric organic load (VOL) from 1.3 to $5.8 \mathrm{~g} \mathrm{COD}(\mathrm{L} \mathrm{d})^{-1}$, and achieved efficiencies of 74.0 to $78.7 \%$ for COD, with swine wastewater with COD from 7.3 to $30.9 \mathrm{~g} \mathrm{~L}^{-1}$. RODRIGUES et al. (2010) evaluated the performance of UASB reactor of 11,500 L operated at VOL from 1.1 to $17.5 \mathrm{~g}$ COD (L d) $)^{-1}$, HDT of 1.7 to $4.1 \mathrm{~d}$, average temperature of $20{ }^{\circ} \mathrm{C}$, fed decanted swine wastewater with COD of $14.8 \mathrm{~g} \mathrm{~L}^{-1}$ and TSS of $2.7 \mathrm{~g} \mathrm{~L}^{-1}$, and observed average removal efficiencies of COD of $85 \%$ and $63 \%$ of TSS.

However, it is possible to enhance the removal of pollutants from swine wastewater and to decrease the volume of UASB reactors by using the procedure in two stages. According to SANTANA \& OLIVEIRA (2005), BICHUETTE et al. (2008), OLIVEIRA et al. (2008), ABREU NETO \& OLIVEIRA (2009), DUDA \& OLIVEIRA (2009 and 2011), TREVISAN \& MONTEGGIA (2009) and OLIVEIRA \& SANTANA (2011), with the anaerobic treatment systems in two stages it was possible to increase removals of suspended solids, COD, nutrients, metals, and coliform bacteria with reduced HDT and to increased stability even with fluctuations of organic and hydraulic load.

SANTANA \& OLIVEIRA (2005) and OLIVEIRA \& SANTANA (2011) treated swine wastewater in a wide range of TSS concentrations ( 2.2 to $\left.16.4 \mathrm{~g} \mathrm{~L}^{-1}\right)$ and total COD (8.8 to $28.5 \mathrm{~g} \mathrm{~L}^{-}$ ${ }^{1}$ ) using two-stage UASB reactors with HDT from 82.2 to $20.0 \mathrm{~h}$ and VOL from 3.4 to $24.4 \mathrm{~g}$ total $\mathrm{COD}(\mathrm{L} \mathrm{d})^{-1}$, and achieved removal efficiencies of 53 to $93 \%$ for total COD, 52 to $89 \%$ for TSS, 21 to $63 \%$ for TKN and 28 to $57 \%$ for total-P.

Despite the good results, the anaerobic reactors hardly produce effluents that meet the standards established by the Brazilian environmental legislation (FORESTI et al., 2006), even in two stages (OLIVEIRA \& SANTANA, 2011). Therefore, the post-treatment for removing the remaining of COD and constituents less affected in anaerobic process, such as nutrients, and pathogens is required. According to CHERNICHARO (2006), the use of combined anaerobicaerobic processes provides advantages such as low power required for aeration in the aerobic phase, lower production of biological sludge and low cost of deployment and operation.

The reactor operated in sequencing batch (SBR) has been investigated for the secondary and tertiary treatment of swine wastewater (BERNET et al, 2000; ZHANG et al, 2006; DENG et al, 2008; OLIVEIRA et al, 2008; OLIVEIRA \& SANTANA, 2011). The fundamental characteristic of SBR is the flexibility of the steps of a cycle of operation, which allows the sequential establishment of process conditions (anaerobic, anoxic and aerobic) to promote greater efficiency transformations required for the biological removal of organic matter remaining, coliforms and nutrients from the anaerobic effluent.

Treating swine wastewater with COD of $19 \mathrm{~g} \mathrm{~L}^{-1}$ and TSS of $9.7 \mathrm{~g} \mathrm{~L}^{-1}$, in a two-stage UASB 
followed by a sequencing batch reactor fed continuously (SBR), with HDT of $13.8 \mathrm{~d}$, OLIVEIRA et al. (2008) obtained effluent with total COD of $221 \mathrm{mg} \mathrm{L}^{-1}$, dissolved COD of $100 \mathrm{mg} \mathrm{L}^{-1}$ and thermotolerant coliform count of $2.0 \times 10^{3} \mathrm{MPN}(100 \mathrm{~mL})^{-1}$, which is below the limit of 4,000 MPN $\left(100 \mathrm{~mL}^{-1}\right.$, which in class 3 fresh water is classified for the use in irrigation of tree crops, grain and fodder (BRASIL, 2005).

Thus, for the treatment of swine wastewater, studies are needed for the development of projects with increased removal efficiency of organic matter, nutrients and pathogens in these systems. This study evaluated the performance of two sets of two-stage UASB reactors, with and without post-treatment at the SBR, for the removal of organic matter, nitrogen, phosphorus and coliforms from swine wastewater, varying HDT and VOL, with two relations between the volumes of anaerobic reactors of the first and second stages.

\section{MATERIAL AND METHODS}

The experimental units consisted of boxes for storing the affluent, helical pumps and two sets (I and II) with two upflow anaerobic sludge blanket (UASB) each, installed in series (R1 and R2). In the set I the useful volume (V) of the R1 was $908 \mathrm{~L}$ and R2 of $350 \mathrm{~L}$, with VR2 $=0.4 \mathrm{VR} 1$. In set II, the VR1 was of $908 \mathrm{~L}$ and the VR2 of $188 \mathrm{~L}$ with VR2 $=0.2 \mathrm{VR} 1$. The post-treatment of the effluent from set II was carried out in a sequencing batch reactor fed continuously (SBR), with aerobic stage, constructed of polyethylene, with $\mathrm{V}=3,000 \mathrm{~L}$. An air compressor, with an average flow of $1.87 \mathrm{~m}^{3} \mathrm{~h}^{-1}$, injected air for five circular coarse bubble membrane diffusers brand BF Dias, installed in the lower region of the SBR, effecting aeration and mixing of the liquid inside the reactor in the aerobic step (Figure 1).

Sets I and II were operated simultaneously. The feeding of the affluent for UASB reactors of the first stage (R1) was carried out by means of a helical pump, and from these routed by gravity in PVC pipes of $1 \frac{1 / 2}{2}$ to the inside of the respective reactors of the second stage (R2). The UASB reactors of the first stage were fed with sieved swine wastewater (sieve with $3 \mathrm{~mm}$ square mesh), reaching average concentrations of total suspended solids (TSS) in the affluent from 9135 to 13160 $\mathrm{mg} \mathrm{L}^{-1}$.
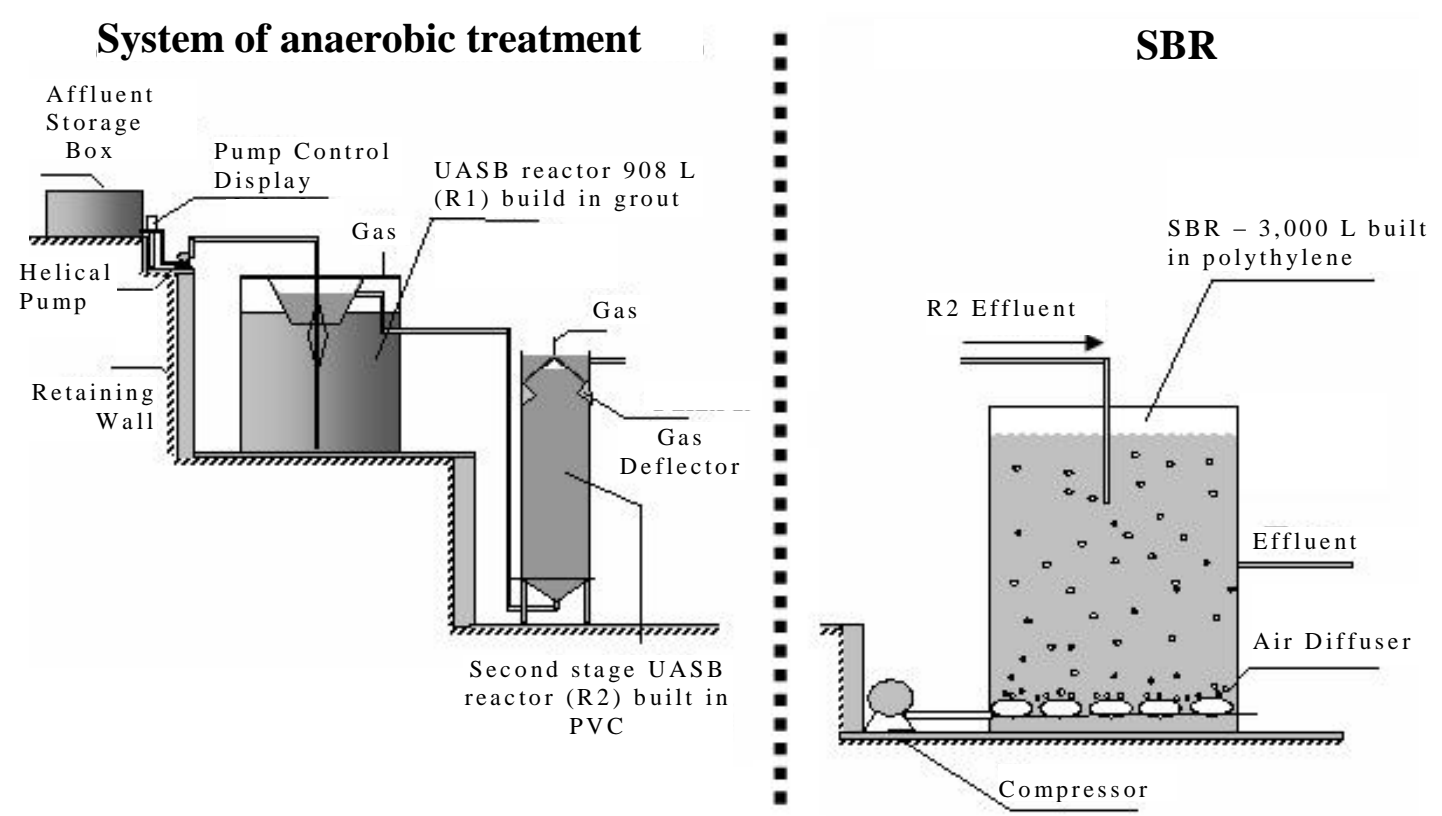

FIGURA 1. Scheme of the two-stage UASB reactors (R1 and R2), in the sets I and II (left), and of the sequencing batch reactor fed continuously (SBR) (right) installed at the exit of R2 of the set II.

The experiment was divided into three assays of 51, 137 and 96 days. The HDT in the anaerobic reactors used systems were 100,75 and $58 \mathrm{~h}$ and 87,65 and $51 \mathrm{~h}$ in sets I and II in assays 
1, 2 and 3, respectively. The volumetric organic load (VOL) applied in R1 were increased by 6.9, 9.4 and $12.7 \mathrm{~g}$ total COD $(\mathrm{L} \mathrm{d})^{-1}$ and $7.5,8.0$ and $9.8 \mathrm{~g}$ total COD $(\mathrm{L} \mathrm{d})^{-1}$, in assays 1,2 and 3 , of the sets I and II, respectively (Table 1).

The HDT used in the SBR was of $240 \mathrm{~h}$ in assay 1. In assays 2 and 3, HRT of $240 \mathrm{~h}$ was initially used, which was subsequently reduced to $180 \mathrm{~h}$. These HDT were adopted similar to those used by OLIVEIRA et al. (2008), who obtained SBR effluent of good quality for COD and coliform.

The SBR was continuously fed with the entire effluent from the second UASB (R2) of the set II, which resulted in a volume of $900 \mathrm{~L}$ per cycle in assay 1 . In assays 2 and 3 , the initial feeding volume was of $900 \mathrm{~L}$ and then of 1,200L per cycle. These values were 30 and $40 \%$, respectively, of the volume of the SBR, which were also considered as the volume of supernatant to be removed in each cycle. Consequently, maintaining 60 to $70 \%$ of the volume of the SBR as settled sludge was adopted based on the recommendation of METCALF \& EDDY (2003).

In order to evaluate the effect of air volume injected per cycle at the SBR, in assays 1, 2 and 3 , aeration times were of 4,10 and $8 \mathrm{~h}$, respectively (Table 2). This started from the aeration time used by OLIVEIRA et al. (2008), which has been increased to improve the conditions for nitrification and therefore to remove ammonia nitrogen $\left(\mathrm{N}_{\mathrm{am}}\right)$ and total nitrogen (TN). Variations in the characteristics of operating cycles, regarding the feeding volume of the sequencing batch reactor fed constinuously (SBR), were made in order to carry out the post-treatment of the entire effluent produced in the anaerobic treatment of the set II, testing different HDT and aerobic reaction times.

TABLE 1. Operation time and conditions of the two-stage UASB reactors (R1 and R2) and of the sequencing batch reactor fed constinuously (SBR) in the sets I and II and assays 1, 2 and 3.

\begin{tabular}{|c|c|c|c|c|c|c|c|c|c|}
\hline \multirow{2}{*}{ Assay } & \multirow{2}{*}{$\begin{array}{c}\text { Operation } \\
\text { Time (d) }\end{array}$} & \multirow{2}{*}{$\begin{array}{c}\text { UASB } \\
\text { Reactors } \\
\text { set }\end{array}$} & \multicolumn{3}{|c|}{ HDT (h) } & \multicolumn{4}{|c|}{ VOL $\left(g\right.$ total COD $\left.(\mathrm{L} \mathrm{d})^{-1}\right)$} \\
\hline & & & R1 & $\mathbf{R 2}$ & SBR & R1 & $\mathbf{R 2}$ & & \\
\hline \multirow{2}{*}{1} & \multirow{2}{*}{54} & $\mathrm{I}^{(1)}$ & 72 & 28 & --- --- & 6.9 & 0.7 & --- & -- \\
\hline & & II & 72 & 15 & 240 & 7.5 & 1.6 & \multicolumn{2}{|c|}{0.081} \\
\hline \multirow{2}{*}{2} & \multirow{2}{*}{137} & $\mathrm{I}^{(1)}$ & 54 & 21 & --- --- & 9.4 & 0.9 & --- & --- \\
\hline & & II & 54 & 11 & $240 \quad 180$ & 8.0 & 1.6 & 0.054 & 0.072 \\
\hline \multirow{2}{*}{3} & \multirow{2}{*}{97} & $I^{(1)}$ & 42 & 16 & $---\quad---$ & 12.7 & 1.2 & --- & --- \\
\hline & & II & 42 & 9 & $240 \quad 180$ & 9.8 & 2.4 & 0.061 & 0.081 \\
\hline
\end{tabular}

HDT: hydraulic detention time, VOL: volumetric organic load, (1) set without post-treatment.

Initially, a sedimentation time of $2.5 \mathrm{~h}$ and of $0.5 \mathrm{~h}$ to remove of supernatant were adopted, which were successfully used by OLIVEIRA et al. (2008). In assay 2, the sedimentation time was reduced to $2.0 \mathrm{~h}$ owing to find good sludge characteristics. In the third assay, this time was increased to $4.0 \mathrm{~h}$ seeking further improvement of the effluent quality decreasing VSS concentration. The other times of $65.0,59.5$ and $59.5 \mathrm{~h}$ (cycle time minus the time of the aerobic reaction, sedimentation and supernatant removal) adopted as anaerobic reaction in test 1,2 and 3 , respectively, were obtained by the difference regarding the time of the SBR cycle of $72 \mathrm{~h}$ (Table 2). The sequence of the steps of the cycle (anaerobic, aerobic, sedimentation and disposal) was defined considering the operation of the SBR with the possibility of removal of COD, N and P, based on the recommendations of METCALF \& EDDY (2003) and WEF \& ASCE (1998a and 2005).

At the beginning of each assay the disposal of sludge was held in all UASB reactors (R1 and $\mathrm{R} 2$ ), leaving $30 \%$ of the volume of each reactor filled with sludge, which served as inoculum. In the SBR the sludge was maintained in all assays. In sets I and II and SBR, the first assay was initiated after the completion of the researches by BICHUETTE et al. (2008) and DUDA et al. (2009). 
TABLE 2. Characteristics of operational cycles used in the sequential batch reactor fed constinuously (SBR) in the assays 1,2 and 3.

\begin{tabular}{cccccc}
\hline Characteristics of operational cycle l & \multirow{2}{*}{ Assay 1} & \multicolumn{2}{c}{ Assay 2} & \multicolumn{2}{c}{ Assay 3} \\
\hline Operation Time (d) & 54 & 29 & 108 & 44 & 53 \\
\hline HDT (h) & 240 & 240 & 180 & 240 & 180 \\
\hline Cycle time (h) & 72 & 72 & 72 & 72 & 72 \\
\hline Feeding volume/cycle (L) & 900 & 900 & 1,200 & 900 & 1,200 \\
\hline Feeding volume/ day (L) & 300 & 300 & 400 & 300 & 400 \\
\hline Feeding time (h) & 72 & 54 & 72 & 42 & 56 \\
\hline Anaerobic reaction time (h) & 65.0 & 59.5 & 59.5 & 59.5 & 59.5 \\
\hline Aerobic reaction time (h) & 4 & 10 & 10 & 8 & 8 \\
\hline Sedimentation time (h) & 2.5 & 2.0 & 2.0 & 4.0 & 4.0 \\
\hline Supernatant removal time (h) & 0.5 & 0.5 & 0.5 & 0.5 & 0.5 \\
\hline
\end{tabular}

HDT: hydraulic detention time.

Twice weekly, composite samples were collected at the exits of each of UASB reactors (R1 and R2) and of the SBR. In these samples determinations of partial (AP) and total (TA) alkalinities, $\mathrm{pH}$, temperature, Kjeldahl nitrogen $(\mathrm{KN})$, ammonia nitrogen $\left(\mathrm{N}_{\mathrm{am}}\right)$, organic nitrogen $(\mathrm{Norg}=\mathrm{KN}-$ Nam), nitrate $\left(\mathrm{N}_{-} \mathrm{NO}_{3}{ }^{-}\right)$, nitrite $\left(\mathrm{N}^{-\mathrm{NO}_{2}}{ }^{-}\right)$, total nitrogen $\left(\mathrm{NT}=\mathrm{KN}+\mathrm{N}-\mathrm{NO}_{3}{ }^{-}+\mathrm{N}^{-} \mathrm{NO}_{2}{ }^{-}\right)$, total phosphorus $\left(\mathrm{P}_{\text {total }}\right)$, total oxygen chemical demand (total $\mathrm{COD}$ ) and dissolved oxygen chemical demand (CODdiss), total (TSS) and volatile (VSS) suspended solids as described by APHA et al. (2005), JENKINS et al. (1983) and SANTANA \& OLIVEIRA (2005), and total volatile fatty acids (VFA) according to DILALLO \& ALBERTSON (1961) were performed. Twice, at the end of each assay, we determined the most probable number (MPN) of total and thermotolerant coliforms in all affluent and effluent, with the multiple tube technique described in APHA et al. (2005).

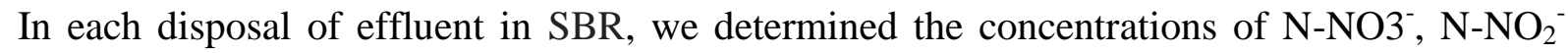
dissolved oxygen (DO) and temperature, as described by APHA et al. (2005).

The daily average air temperatures were obtained from the agrometeorological station of Exact Sciences Department, UNESP, Campus of Jaboticabal (UNESP, 2011).

The daily biogas production in UASB reactors were monitored through measures in gasometers (SANTANA \& OLIVEIRA, 2005). Biogas composition was determined weekly by gas chromatography as described in APHA et al. (2005).

\section{RESULTS AND DISCUSSION}

The average values of daily average air temperature were $21.9,21.6$ and $24.5^{\circ} \mathrm{C}$, in assays 1,2 and 3 respectively, with average daily temperature ranges of $14.0,9.0,12.0$, and $12.5^{\circ} \mathrm{C}$, respectively. Thus, it was found that the reactors were operated predominantly in the mesophilic range $\left(20^{\circ} \mathrm{C}\right.$ to $\left.45^{\circ} \mathrm{C}\right)$, considered suitable for the anaerobic process, but below the optimum temperature of $35^{\circ} \mathrm{C}$ for the multiplication of microorganisms, cited by GERARDI (2003).

The average values of total alkalinity (TA) in the affluent remained between 914 and $1091 \mathrm{mg}$ $\mathrm{L}^{-1}$ and partial alkalinity (PA) between 267 and $375 \mathrm{mg} \mathrm{L}^{-1}$ (Table 3). These values increased during the passage through the UASB reactors, in all assays. In the sets I and II, TA effluents ranging from 1,005 to $1,224 \mathrm{mg} \mathrm{L}^{-1}$ and PA from 687 to $887 \mathrm{mg} \mathrm{L}^{-1}$ were obtained. There was contribution of the alkalinity found in the affluents, as also evidenced by ABREU \& OLIVEIRA NETO (2009) when using a reactor compartment (ABR) followed by a UASB reactor for treating swine wastewater. In the effluents of two-stage UASB reactors, SANTANA \& OLIVEIRA (2005) and OLIVEIRA \& 
SANTANA (2011) found higher values of TA, 848 to $3492 \mathrm{mg} \mathrm{L}^{-1}$ and PA, 610 to $960 \mathrm{mg} \mathrm{L}^{-1}$, because of the wider range of VOL applied to the R1, from 3.4 to $24.4 \mathrm{~g}$ total COD (L d $)^{-1}$.

TABLE 3. Average values and coefficients of variation (cv) of $\mathrm{pH}$, total alkalinity (TA), partial alkalinity (PA) and total volatile fatty acids (VFA) in the affluent and effluent, obtained during operation of the two-stage UASB reactors (R1 and R2) and the sequential batch reactor fed constinuously (SBR) of the sets I and II, in the assays 1 to 3.

\begin{tabular}{|c|c|c|c|c|c|c|c|c|c|c|}
\hline \multirow{3}{*}{ Assay } & \multirow{3}{*}{ Set } & \multirow{3}{*}{ Sample } & \multirow{3}{*}{$\begin{array}{c}\mathrm{HDT}^{1} \\
(\mathrm{~h})\end{array}$} & \multirow{3}{*}{$\mathrm{VOL}_{(2)}{ }^{1}$} & \multicolumn{6}{|c|}{ Attribute } \\
\hline & & & & & $\mathrm{pH}$ & $\mathrm{TA}^{2}$ & \multicolumn{2}{|c|}{$\mathrm{PA}^{2}$} & \multicolumn{2}{|c|}{$\mathrm{VFA}^{2}$} \\
\hline & & & & & $\mathrm{A}^{1} \quad \mathrm{cv}^{2}$ & $\mathrm{~A}^{1} \quad \mathrm{cv}^{2}$ & $\mathrm{~A}^{1}$ & $c v^{2}$ & $\mathrm{~A}^{1}$ & $\mathrm{cv}^{2}$ \\
\hline \multirow{7}{*}{1} & \multirow{3}{*}{ I } & Affl. & --- & --- & 6.57 & $1,074 \quad 31$ & 326 & 50 & 530 & 52 \\
\hline & & Effl. R1 & 72 & 6.9 & 7.02 & $1,132 \quad 22$ & 805 & 22 & 211 & 56 \\
\hline & & Effl. R2 & 28 & 0.7 & 7.23 & $1,144 \quad 19$ & 830 & 19 & 174 & 52 \\
\hline & \multirow{4}{*}{ II } & Affl. & --- & --- & 6.55 & $1,020 \quad 22$ & 291 & 47 & 493 & 45 \\
\hline & & Effl. R1 & 72 & 7.5 & 7.03 & $1,170 \quad 18$ & 834 & 23 & 227 & 46 \\
\hline & & Effl. R2 & 15 & 1.6 & 7.22 & $1,203 \quad 18$ & 887 & 18 & 195 & 46 \\
\hline & & Effl.SBR & 72 & 0.081 & 7.62 & $1,262 \quad 11$ & 947 & 14 & 206 & 40 \\
\hline \multirow{8}{*}{2} & \multirow{3}{*}{ I } & Affl. & --- & --- & 6.48 & $970 \quad 38$ & 363 & 52 & 629 & 50 \\
\hline & & Effl. R1 & 54 & 9.4 & 6.93 & $986 \quad 27$ & 656 & 32 & 200 & 58 \\
\hline & & Effl. R2 & 21 & 0.9 & 7.23 & $1,025 \quad 29$ & 719 & 30 & 190 & 55 \\
\hline & \multirow{5}{*}{ II } & Affl. & --- & --- & 6.59 & $914 \quad 38$ & 375 & 47 & 602 & 51 \\
\hline & & Effl. R1 & 54 & 8.0 & 6.93 & 98426 & 647 & 30 & 199 & 56 \\
\hline & & Effl. R2 & 11 & 1.6 & 7.24 & $1,005 \quad 25$ & 687 & 29 & 195 & 62 \\
\hline & & Effl. & 240 & 0.054 & 7.54 & 7204 & 552 & 5 & 137 & 40 \\
\hline & & SBR & 180 & 0.072 & 7.74 & $992 \quad 33$ & 674 & 40 & 195 & 58 \\
\hline \multirow{8}{*}{3} & \multirow{3}{*}{ I } & Affl. & --- & --- & 6.45 & $1,091 \quad 49$ & 268 & 59 & 732 & 47 \\
\hline & & Effl. R1 & 42 & 12.6 & 7.14 & $1,171 \quad 39$ & 820 & 40 & 312 & 109 \\
\hline & & Effl. R2 & 16 & 1.2 & 7.33 & $1,215 \quad 42$ & 862 & 42 & 312 & 124 \\
\hline & \multirow{5}{*}{ II } & Affl. & --- & --- & 6.45 & 1,03950 & 267 & 54 & 674 & 38 \\
\hline & & Effl. R1 & 42 & 9.8 & 7.13 & 1,18243 & 827 & 46 & 266 & 54 \\
\hline & & Effl. R2 & 9 & 2.4 & 7.32 & $1,224 \quad 45$ & 866 & 44 & 231 & 53 \\
\hline & & Effl. & 240 & 0.061 & 7.71 & $1,082 \quad 50$ & 819 & 51 & 234 & 48 \\
\hline & & SBR & 180 & 0.081 & 7.82 & $1,252 \quad 21$ & 935 & 22 & 179 & 77 \\
\hline
\end{tabular}

${ }^{1}$ HDT: hydraulic detention time, VOL: volumetric organic load , A: average, ${ }^{2}$ Units: VOL: g total COD (L d) ${ }^{-1}$, TA and PA: mg L ${ }^{-1}$ of $\mathrm{CaCO}_{3}$, VFA: $\mathrm{mg} \mathrm{L}^{-1}$ of $\mathrm{CH}_{3} \mathrm{COOH}$, cv: $\%$.

The $\mathrm{pH}$ of the effluent ranged from 6.4 to 6.5. After R1, with the generation of alkalinity, the values stabilized between 6.9 and 7.1 in the effluent. In $\mathrm{R} 2$ the $\mathrm{pH}$ values increased, reaching average values of 7.2 and 7.3 (Table 3 ). There were increases in alkalinity in the UASB reactors under any of the conditions imposed, being the carbon dioxide system always efficient in the maintenance of the $\mathrm{pH}$ in the range from 6.6 to 7.4; cited as great by CHERNICHARO (2007).

There was intake of total volatile fatty acids (VFA) in two-stage UASB reactors in all assays. In the affluent the values ranged from 493 to $732 \mathrm{mg} \mathrm{L}^{-1}$, decreasing to values from 174 to $312 \mathrm{mg}$ $\mathrm{L}^{-1}$ in the effluent of R2 (Table 3), demonstrating that there was no accumulation in any of the conditions imposed in the assays. The average values of VFA were below the limit of $500 \mathrm{mg} \mathrm{L}^{-1}$, recommended by GERARDI (2003), indicating that the process remained stable during the assays.

With lower VOL, SONG et al. (2010) obtained higher values of $\mathrm{pH}$ in the effluent, from 7.8 to 8.2 , and reductions of VFA, of 89 to $97 \%$. SANTANA \& OLIVEIRA (2005) and BICHUETTE et al. (2008), with similar VOL from 5.2 to $14,4 \mathrm{~g}$ total COD $(\mathrm{L} \mathrm{d})^{-1}$, observed similar pH values in the range from 7.1 to 7.5 , and TVA from 75 to $177 \mathrm{mg} \mathrm{L}^{-1}$. OLIVEIRA \& SANTANA (2011) applied VOL of up to $24.4 \mathrm{~g}$ total COD $(\mathrm{L} \mathrm{d})^{-1}$ and there were no marked changes in $\mathrm{pH}$ and VFA 
compared to those obtained in this work. Therefore, the imposed conditions of HDT and VOL in a two-stage UASB were adequate to maintain balance between production and consumption of alkalinity and volatile fatty acids.

In the affluent, the average values of total COD in assays 1, 2 and 3 ranged from 20,755 to $22,105 \mathrm{mg} \mathrm{L}^{-1}$ in set I and from 17,086 to $22,382 \mathrm{mg} \mathrm{L}^{-1}$ in set II (Table 4). The high values of coefficient of variation (cv 51 to 103\%) to the average of total COD and TSS of the affluent were due to changes in the composition of the affluent by variations in age and management of animals, as was also observed by SANTANA \& OLIVEIRA (2005), OLIVEIRA et al. (2008), ABREU NETO \& OLIVEIRA (2009), RODRIGUES et al. (2010) and OLIVEIRA \& SANTANA (2011). It was observed that, even with these changes, the anaerobic treatment systems remained stable, showing its robustness in situations that may occur in pig properties.

The average values of total COD removal efficiencies were high and suffered slight decrease, from 95 to 94 and $93 \%$ in the set I, with increased VOL from 6.9 to 9.4 and $12.6 \mathrm{~g}$ total COD (L d) ${ }^{1}$ in R1, respectively, in assays 1, 2 and 3. In set II, the average total COD removal efficiencies were similar to those observed in the set I with values of 95,92 and $90 \%$ in assays 1,2 and 3, and also decreased with increased VOL from 7.5 to 8.0 and $9.8 \mathrm{~g}$ total COD (L d) ${ }^{-1}$, respectively (Table 5). Accordingly, with the highest HDT, of $72 \mathrm{~h}$ in assay 1, when occurred the lowest VOL in R1 in sets I and II, it was possible to obtain the greatest efficiency of total COD removal (95\%) in both $\mathrm{R} 1$.

These removals of total COD were higher than those obtained by RODRIGUES et al. (2010), due to higher HDT used in R1 reactors. It may also be associated with higher fractions of volatile suspended solids in the affluent, which favored the removal of organic matter particulate by sedimentation and interception in the sludge blanket. The efficiencies obtained by SONG et al. (2010) were also lower, possibly because a full scale UASB with greater production of biogas increases turbulence and dragging of suspended solids with the effluent.

In R2, the average total COD removal efficiencies were lower, of 38, 45 and $37 \%$ in set I and of 25, 33 and $39 \%$ in set II in assays 1, 2 and 3, respectively. The highest average value of total COD of $22382 \mathrm{mg} \mathrm{L}^{-1}$ in the affluent of the set II made its R2 receive effluent with total COD of $1007 \mathrm{mg} \mathrm{L}^{-1}$, a value higher than that observed in the effluent of $\mathrm{R} 1$ in the set I. This resulted in a marked increase in the VOL in R2 of set II, due to the lower volume, and contributed to the decrease of the total COD removal (25\%) in relation to that obtained in R2 of set I (38\%).

With an R2 of smaller volume under similar VOL of $1.6 \mathrm{~g}$ total COD $(\mathrm{L} \mathrm{d})^{-1}$, in assays 1 and 2, a higher removal efficiency of total COD was observed using the lowest HDT of $11 \mathrm{~h}$ in the assay 2. This can be explained by the dragging of the sludge of the R2 of set I in assay 1, with coefficients of variation for total suspended solids of $198 \%$ (Table 4), which may have occurred due to higher daily temperature ranges.

Even with such variations in the affluent and hence in the VOL applied in the reactors R1 and $\mathrm{R} 2$, in the anaerobic treatment systems $(\mathrm{R} 1+\mathrm{R} 2)$ total COD removal efficiencies were observed with slight differences of 97, 96 and 94\% and $96,94 \%$ and 94 in sets I and II in tests 1, 2 and 3, respectively (Table 5). 
TABLE 4. Average values and coefficients of variation (cv) of total chemical oxygen demand (total COD) and dissolved ( $\mathrm{COD}_{\text {diss }}$ ), and of total (TSS) and volatile suspended solids (VSS) concentrations in the affluent and effluent obtained during operation of the two-stage UASB reactors (R1 and R2) and the sequential batch reactor fed constinuously (SBR) of the sets I and II, in the assays 1 to 3 .

\begin{tabular}{|c|c|c|c|c|c|c|c|c|c|c|c|c|}
\hline \multirow{3}{*}{ Assay } & \multirow{3}{*}{ Set } & \multirow{3}{*}{ Sample } & \multirow{3}{*}{$\begin{array}{c}\mathrm{HDT}^{1} \\
\text { (h) }\end{array}$} & \multirow{3}{*}{$\mathrm{VOL}_{(2)}^{1}$} & \multicolumn{8}{|c|}{ Atribute } \\
\hline & & & & & \multicolumn{2}{|c|}{ total $\mathrm{COD}^{2}$} & CODc & ss. $^{2}$ & \multicolumn{2}{|c|}{$\mathrm{TSS}^{2}$} & \multicolumn{2}{|c|}{$\mathrm{VSS}^{2}$} \\
\hline & & & & & & $c v^{2}$ & & $\mathrm{cv}^{2}$ & $\mathrm{~A}^{1}$ & $\mathrm{cv}^{2}$ & $\mathrm{~A}^{1}$ & $\mathrm{cv}^{2}$ \\
\hline \multirow{7}{*}{1} & \multirow{3}{*}{ I } & Affl. & --- & --- & 20,75 & 51 & 1,423 & 67 & 11,819 & 77 & 3,433 & 54 \\
\hline & & Effl. R1 & 72 & 6.9 & 841 & 32 & 235 & 31 & 829 & 184 & 299 & 225 \\
\hline & & Effl. R2 & 28 & 0.7 & 536 & 37 & 208 & 38 & 354 & 198 & 142 & 44 \\
\hline & \multirow{4}{*}{ II } & Affl. & --- & -- & 22,382 & 57 & 2,251 & 61 & 9,135 & 69 & 4,855 & 82 \\
\hline & & Effl. R1 & 72 & 7.5 & 1,007 & 54 & 363 & 42 & 554 & 109 & 284 & 111 \\
\hline & & Effl. R2 & 15 & 1.6 & 808 & 39 & 321 & 54 & 653 & 109 & 359 & 133 \\
\hline & & Effl. SBR & 240 & 0.081 & 325 & 26 & 187 & 44 & 131 & 84 & 59 & 51 \\
\hline \multirow{8}{*}{2} & \multirow{3}{*}{ I } & Affl. & --- & -- & 21,239 & 80 & 1,530 & 69 & 13,160 & 77 & 7,405 & 83 \\
\hline & & Effl. R1 & 54 & 9.4 & 78 & 75 & 180 & 34 & 429 & 91 & 221 & 90 \\
\hline & & Effl. R2 & 21 & 0.9 & 392 & 50 & 167 & 46 & 179 & 148 & 122 & 148 \\
\hline & \multirow{5}{*}{ II } & Affl. & --- & -- & 17,905 & 90 & 1,217 & 59 & 10,706 & 77 & 6,049 & 83 \\
\hline & & Effl. R1 & 54 & 8.0 & 747 & 67 & 162 & 37 & 455 & 114 & 262 & 96 \\
\hline & & Effl. R2 & 11 & 1.6 & 53 & 63 & 150 & 52 & 244 & 75 & 145 & 64 \\
\hline & & \multirow{2}{*}{ Effl. SBR } & 240 & 0.054 & 135 & 26 & 92 & 46 & 30 & 34 & 24 & 41 \\
\hline & & & 180 & 0.072 & $22 ?$ & 32 & 130 & 24 & 85 & 42 & 60 & 51 \\
\hline \multirow{8}{*}{3} & \multirow{3}{*}{ I } & Affl. & --- & --- & 22,105 & 84 & 1,593 & 40 & 11,693 & 89 & 5,228 & 103 \\
\hline & & Effl. R1 & 42 & 12.6 & 818 & 59 & 252 & 52 & 471 & 123 & 312 & 165 \\
\hline & & Effl. R2 & 16 & 1.2 & 705 & 87 & 198 & 47 & 317 & 107 & 156 & 94 \\
\hline & \multirow{5}{*}{ II } & Affl. & --- & --- & 17,086 & 76 & 1,877 & 42 & 9,657 & 87 & 5,044 & 99 \\
\hline & & Effl. R1 & 42 & 9.8 & 872 & 61 & 220 & 35 & 325 & 95 & 159 & 61 \\
\hline & & Effl. R2 & 9 & 2.4 & 606 & 53 & 164 & 35 & 279 & 62 & 201 & 118 \\
\hline & & \multirow{2}{*}{ Effl. SBR } & 240 & 0.061 & 248 & 36 & 137 & 47 & 89 & 68 & 55 & 78 \\
\hline & & & 180 & 0.081 & 221 & 27 & 139 & 22 & 97 & 59 & 57 & 74 \\
\hline
\end{tabular}

HDT: hydraulic detention time, VOL: volumetric organic load, A: average ${ }^{2}$ Units: VOL: g total COD (L d) ${ }^{-1}$, COD, TSS and VSS: $\mathrm{mg} \mathrm{L}-1, \mathrm{cv}: \%$.

In general, comparing the sets I and II in each assay, operated under the same conditions of temperature and HDT in R1, it was observed that in the assays 1 and 2 the total COD removal efficiencies of the anaerobic treatment system $(\mathrm{R} 1+\mathrm{R} 2)$ were slightly higher in set I, which had the lowest volume ratio (VR1/VR2) with HDT of the system (R1 + R2) about 15\% higher than those applied in set II. In the third assay, with HDT of $58 \mathrm{~h}(\mathrm{R} 1+\mathrm{R} 2)$ that did not happen, but the set I was able to keep the same efficiency of $94 \%$ observed in set II, even when operating with higher VOL in R1. In the assay 2, the highest VOL applied in R1 of the set I also did not stop it from reaching total COD removal slightly higher than that observed in set II.

With the placement of the second-stage reactor (R2), the sets I and II obtained effluent with lower average values of total COD and their coefficients of variation (except for assay 3 of set I) (Table 4) . Therefore, a better performance with greater stability occurred. However, the highest volume of $\mathrm{R} 2$ in the set I did not provide a proportional increase of the total COD removal efficiencies.

Using the set I, BICHUETTE et al. (2008) found similar efficiencies of total COD removal, of $97 \%$, when they applied VOL of 5.2 and $8.6 \mathrm{~g}$ total COD $(\mathrm{L} \mathrm{d})^{-1}$ in R1 and HDT of 100 and $75 \mathrm{~h}$, respectively, in the anaerobic treatment system $(\mathrm{R} 1+\mathrm{R} 2)$. In set II, SANTANA \& OLIVEIRA (2005) obtained 93\% removal of total COD with VOL of $7.4 \mathrm{~g}$ total COD $(\mathrm{L} \mathrm{d})^{-1}$ in R1 and HDT of $37.6 \mathrm{~h}$ in $\mathrm{R} 1+\mathrm{R} 2$. Thus, it was confirmed that it is possible to obtain high total COD removal 
efficiencies with anaerobic treatment systems in two stages under the conditions of HDT and VOL applied in this work. However, when SANTANA \& OLIVEIRA (2005) increased the VOL to 14.4 $\mathrm{g}$ total COD $(\mathrm{L} \mathrm{d})^{-1}$ in $\mathrm{R} 1$ with HDT of $37.6 \mathrm{~h}$ in $\mathrm{R} 1+\mathrm{R} 2$, the average total COD removal efficiency decreased to 87\%, indicating that the reduction of the HDT with an increase in VOL for values above the ones cited and used in this work may cause more pronounced decreases in total COD removal.

With the high total COD removal efficiencies verified in both sets of two-stage UASB reactors treating swine wastewater, it was possible to produce effluents of $\mathrm{R} 2$ reactors with total COD ranging from 392 to $808 \mathrm{mg} \mathrm{L}^{-1}$ (Table 4).

TABLE 5. Average values and coefficients of variation (cv) of the methane volumetric production (MVP) and of the removal efficiencies of total (total COD) and dissolved chemical oxygen demand (COD diss), and total (TSS) and volatile suspended solids (VSS), during operation of the two-stage UASB reactors (R1 and R2) and the sequential batch reactor fed constinuously (SBR) of the sets I and II, in the assays 1 to 3.

\begin{tabular}{|c|c|c|c|c|c|c|c|c|c|c|c|c|c|c|}
\hline \multirow{3}{*}{ Assay } & \multirow{3}{*}{ Set } & \multirow{3}{*}{ Sample } & \multirow{3}{*}{$\begin{array}{c}\mathrm{HDT}^{1} \\
\text { (h) }\end{array}$} & \multirow{3}{*}{$\mathrm{VOL}_{(2)}^{1}$} & \multirow{2}{*}{\multicolumn{2}{|c|}{$\underset{\text { (2) }}{\mathrm{MVP}^{1}}$}} & \multicolumn{8}{|c|}{ Removal efficiencies (\%) } \\
\hline & & & & & & & \multicolumn{2}{|c|}{ total COD } & \multirow{2}{*}{\multicolumn{2}{|c|}{$\frac{\text { CODdiss }}{\mathrm{A}^{1} \mathrm{cv}^{2}}$}} & \multicolumn{2}{|c|}{ TSS } & \multicolumn{2}{|c|}{ VSS } \\
\hline & & & & & $\mathrm{A}^{1}$ & $\mathrm{cv}^{2}$ & $\mathrm{~A}^{1}$ & $\mathrm{Cv}^{2}$ & & & $\mathrm{~A}^{1}$ & $\mathrm{cv}^{2}$ & $\mathrm{~A}^{1}$ & $\mathrm{cv}^{2}$ \\
\hline \multirow{8}{*}{1} & \multirow{3}{*}{ I } & R1 & 72 & 6.9 & 0.287 & 37 & 95 & 3 & 76 & 24 & 97 & 3 & 96 & 3 \\
\hline & & $\mathrm{R} 2$ & 28 & 0.7 & 0.075 & 42 & 38 & 61 & 295 & 52 & 34 & 80 & 56 & 39 \\
\hline & & $\mathrm{R} 1+\mathrm{R} 2$ & 100 & $\begin{array}{l}-- \\
\end{array}$ & 0.228 & 36 & 97 & 3 & 79 & 19 & 97 & 3 & 95 & 4 \\
\hline & \multirow{5}{*}{ II } & $\mathrm{R} 1$ & 72 & 7.5 & 0.400 & 38 & 95 & 3 & 79 & 16 & 92 & 8 & 91 & 10 \\
\hline & & R2 & 15 & 1.6 & 0.234 & 48 & 25 & 78 & 32 & 42 & (3) & --- & (3) & --- \\
\hline & & $\mathrm{R} 1+\mathrm{R} 2$ & 87 & --- & 0.351 & 45 & 96 & 3 & 84 & 8 & 92 & 13 & 90 & 20 \\
\hline & & SBR & 240 & 0.081 & --- & --- & 58 & 25 & 47 & 63 & 71 & 36 & 63 & 41 \\
\hline & & $\mathrm{R} 1+\mathrm{R} 2+\mathrm{SBR}$ & 327 & --- & --- & --- & 98 & 1 & 89 & 7 & 98 & 4 & 97 & 5 \\
\hline \multirow{10}{*}{2} & \multirow{3}{*}{ I } & $\mathrm{R} 1$ & 54 & 9.4 & 0.255 & 51 & 94 & 6 & 83 & 17 & 95 & 6 & 95 & 5 \\
\hline & & $\mathrm{R} 2$ & 21 & 0.9 & 0.099 & 44 & 45 & 43 & $25 \varepsilon$ & 88 & 63 & 31 & 53 & 48 \\
\hline & & $\mathrm{R} 1+\mathrm{R} 2$ & 75 & --- & 0.210 & 51 & 96 & 5 & 85 & 12 & 98 & 2 & 97 & 4 \\
\hline & \multirow{7}{*}{ II } & $\mathrm{R} 1$ & 54 & 8.0 & 0.425 & 54 & 92 & 9 & 83 & 12 & 94 & 6 & 92 & 10 \\
\hline & & $\mathrm{R} 2$ & 11 & 1.6 & 0.179 & 58 & 33 & 68 & 23 & 77 & 44 & 59 & 51 & 47 \\
\hline & & $\mathrm{R} 1+\mathrm{R} 2$ & 65 & --- & 0.376 & 55 & 94 & 7 & 84 & 15 & 96 & 6 & 94 & 9 \\
\hline & & \multirow{2}{*}{ SBR } & 240 & 0.054 & --- & --- & 43 & 47 & 465 & 59 & 43 & 40 & 55 & 38 \\
\hline & & & 180 & 0.072 & --- & --- & 62 & 27 & 395 & 53 & 65 & 28 & 63 & 29 \\
\hline & & \multirow{2}{*}{$\mathrm{R} 1+\mathrm{R} 2+\mathrm{SBR}$} & 305 & --- & --- & --- & 96 & 3 & 782 & 26 & 98 & 2 & 97 & 2 \\
\hline & & & 245 & --- & --- & --- & 97 & 5 & 89 & 11 & 96 & 17 & 98 & 3 \\
\hline \multirow{10}{*}{3} & \multirow{3}{*}{ I } & $\mathrm{R} 1$ & 42 & 12.6 & 0.480 & 52 & 93 & 8 & 82 & 13 & 93 & 9 & 88 & 21 \\
\hline & & $\mathrm{R} 2$ & 16 & 1.2 & 0.193 & 70 & 37 & 40 & $30 \quad$ & 60 & 61 & 41 & 59 & 54 \\
\hline & & $\mathrm{R} 1+\mathrm{R} 2$ & 58 & & 0.377 & 60 & 94 & 7 & 87 & 8 & 96 & 5 & 93 & 12 \\
\hline & \multirow{7}{*}{ II } & $\mathrm{R} 1$ & 42 & 9.8 & 0.454 & 40 & 90 & 12 & 86 & 9 & 92 & 9 & 94 & 6 \\
\hline & & R2 & 9 & 2.4 & 0.196 & 57 & 39 & 59 & 335 & 57 & 40 & 61 & 33 & 54 \\
\hline & & $\mathrm{R} 1+\mathrm{R} 2$ & 51 & --- & 0.402 & 42 & 94 & 6 & 90 & 6 & 93 & 11 & 91 & 15 \\
\hline & & \multirow{2}{*}{ SBR } & 240 & 0.061 & --- & --- & 55 & 34 & 32 & 45 & 68 & 25 & 73 & 20 \\
\hline & & & 180 & 0.081 & $-\cdots$ & --- & 53 & 44 & 273 & 59 & 64 & 41 & 64 & 35 \\
\hline & & \multirow{2}{*}{$\mathrm{R} 1+\mathrm{R} 2+\mathrm{SBR}$} & 291 & --- & -- & --- & 97 & 2 & 92 & 5 & 97 & 6 & 98 & 4 \\
\hline & & & 231 & --- & --- & --- & 97 & 4 & 92 & 3 & 97 & 3 & 96 & 6 \\
\hline
\end{tabular}

HDT: hydraulic detention time, VOL: volumetric organic load, A: average, MVP: methane volumetric production. ${ }^{2}$ Units: VOL: g totalCOD $(\mathrm{L} \mathrm{d})^{-1}$, MVP: $\mathrm{LCH}_{4}(\mathrm{~L} \text { reactor } \mathrm{d})^{-1}, \mathrm{cv}: \% .{ }^{3}$ No removal, or below $1 \%$.

In order to the disposal in water bodies or soil, post-treatment of this anaerobic effluent may be required, even for assays with the best performance of anaerobic treatment systems. Hence the SBR in set II, with which it was possible to obtain average values of total COD and COD $_{\text {diss }}$ in the 
effluent of 135 and $92 \mathrm{mg} \mathrm{L}^{-1}$, respectively, in assay 2. With the same set II, OLIVEIRA et al. (2008) observed slightly higher average values (221 and $100 \mathrm{mg} \mathrm{L}^{-1}$, respectively) with similar operating conditions in the SBR, confirming the possibility to achieve final effluent of good quality using the proposed treatment system. These values of COD can meet the standards for effluent discharge of the legislation of some Brazilian states (VON SPERLING, 2005).

The average removal efficiencies of $\mathrm{COD}_{\text {diss }}$ in the sets I and II ranged from 79 to $90 \%$ in assays 1, 2 and 3 (Table 5). With the inclusion of the SBR in set II it was possible to increase the removal efficiencies to $89-92 \%$ (Table 5).

The average concentrations of TSS in the affluent ranged from 9,657 to $13,160 \mathrm{mg} \mathrm{L}^{-1}$ and from 9,135 to $10,706 \mathrm{mg} \mathrm{L}^{-1}$ in the sets I and II, respectively (Table 4). In effluents from R2 they decreased to average values between 179 and $653 \mathrm{mg} \mathrm{L}^{-1}$. The removal efficiencies of TSS in the anaerobic treatment system reached $98 \%$ in the set I, with HDT of $75 \mathrm{~h}(\mathrm{R} 1+\mathrm{R} 2)$ and VOL in R1 of $9.4 \mathrm{~g}$ total COD $(\mathrm{L} \mathrm{d})^{-1}$ in assay 2 (Table 5). The average removal efficiencies of TSS were similar, 98 and $97 \%$ when BICHUETTE et al. (2008) treated swine wastewater with TSS concentrations of 9,980 and $9,880 \mathrm{mg} \mathrm{L}^{-1}$, in UASB reactors of set I applying VOL of 5.2 and $8.6 \mathrm{~g}$ total COD $(\mathrm{L} \mathrm{d})^{-1}$ in $\mathrm{R} 1$, respectively.

In the SBR, the highest removal efficiencies of $\mathrm{COD}_{\text {diss }}$ and TSS, with values of 47 and $71 \%$, respectively, were obtained with HDT of $240 \mathrm{~h}$ in assay 1. For total COD, the highest removal of $62 \%$, was observed with HDT of $180 \mathrm{~h}$ in assay 2 (Table 5), in which there was an increase of $6 \mathrm{~h}$ in the aeration time.

The average concentrations of total and volatile solids (TS and VS) in sludge from UASB reactors of the sets I and II and SBR were higher at the base and gradually decreased to the top of the reactors. The average values of VS in the sludge of the reactors R1 and R2 of set I varied during the tests, from 35,335 to $1,586 \mathrm{mg} \mathrm{L}^{-1}$ and 36,134 to $3,050 \mathrm{mg} \mathrm{L}^{-1}$ from the base to the top of the reactor, respectively. In the set II, they ranged from 47,946 to $9,369 \mathrm{mg} \mathrm{L}^{-1}$ and 37,854 to $8,621 \mathrm{mg}$ $\mathrm{L}^{-1}$ in the reactors $\mathrm{R} 1$ and $\mathrm{R} 2$, respectively. In the SBR the average values of VS were from 5,360 to $1,852 \mathrm{mg} \mathrm{L}^{-1}$ from the bottom to the top of the reactor.

The high values of TS and VS of the sludge indicate that in the UASB reactors there was maintenance of a predominantly organic, dense and with microbial activity sludge, which was stratified into layers due to the mixing caused by the upward flow of affluent sludge and biogas. In the SBR the concentrations of VS of the sludge remained within the range of the design parameters of SBR for biological removal of COD, N and P recommended by WEF \& ASCE (1998a) and METCALF \& EDDY (2003).

Despite the high removal of total COD in the anaerobic reactors, the volumetric methane productions were low and the average values ranged from 0.255 to $0.480 \mathrm{~L} \mathrm{CH}_{4}(\mathrm{~L} \mathrm{~d})^{-1}$ and from 0.400 to $0.454 \mathrm{~L} \mathrm{CH}_{4}(\mathrm{~L} \mathrm{~d})^{-1}$ in R1 in the sets I and II, respectively (Table 5). The highest average daily temperatures and lowest temperature ranges, associated with higher VOL applied in assay 3, favored microbial activity, resulting in higher average values for the volumetric production of methane. The same occurred for the anaerobic treatment system $(R 1+R 2)$ of both sets.

These values of volumetric methane production were similar to those obtained by OLIVEIRA \& SANTANA (2011), who used similar experimental conditions. However, they were lower than 
those verified by SANTANA \& OLIVEIRA ( 2005), when they operated the set II with VOL from 3.4 to $14.4 \mathrm{~g}$ total COD $(\mathrm{L} \mathrm{d})^{-1}$ in $\mathrm{R} 1$ and reached volumetric productions from 0.594 to $1.130 \mathrm{~L}$ $\mathrm{CH}_{4}(\mathrm{~L} \mathrm{~d})^{-1}$. The lowest concentrations of TSS $\left(2,216\right.$ to $\left.7,131 \mathrm{mg} \mathrm{L}^{-1}\right)$ and smallest sieving mesh size (square mesh sieve with $2 \mathrm{~mm}$ ) of the affluent increased the proportion of the $\mathrm{COD}_{\text {diss }}$ in the total COD and decreased the size of the VSS in the affluent. These characteristics facilitated the conversion of the affluent organic matter into methane and provided the largest volumetric productions obtained by SANTANA \& OLIVEIRA (2005). SONG et al. (2010) also obtained higher methane production, even applying lower VOL (from 1.3 to $5.8 \mathrm{~g} \mathrm{COD}(\mathrm{L} \mathrm{d})^{-1}$ ), possibly due to higher HDT ( 84 to $168 \mathrm{~h}$ ) and swine wastewater sieved with a mesh with an opening smaller than $3 \mathrm{~mm}$.

The average values of $\mathrm{KN}, \mathrm{N}_{\mathrm{am}}$ and $\mathrm{N}_{\text {org }}$ in the affluent varied from 733 to $1,161 \mathrm{mg} \mathrm{L}^{-1}, 178$ to $239 \mathrm{mg} \mathrm{L}^{-1}$ and 546 to $963 \mathrm{mg} \mathrm{L}^{-1}$, respectively (Table 6). Variations in $\mathrm{N}_{\mathrm{am}}$ concentrations in the outlet of UASB reactors were not proportional to the removal of $\mathrm{N}_{\text {org }}$ (78 to $98 \%$ ), which was also observed by DUDA \& OLIVEIRA (2009 and 2011) and OLIVEIRA \& SANTANA (2011). This indicated that high removals of the $\mathrm{N}_{\text {org }}$ fraction occurred predominantly by physical entrapment in the sludge blanket and not by ammonification. The highest removal of the $\mathrm{N}_{\text {org }}$ fraction, of $98 \%$, obtained in assay 1 of set I (Table 6) was favored by lower VOL and higher HDT which led to lower sludge dragging even with the highest temperature ranges in the period, which seem to have affected more pointedly the second stage of lowest volume of set II operated with lower HDT and higher VOL.

Thus, there was reflection in the KN removals, which ranged from 58 to $68 \%$ (Table 6), but not in the increase of the Nam concentration in the effluent from the UASB reactors. Treating swine wastewater in the set I, BICHUETTE et al. (2008) observed similar behavior between the fractions of nitrogen and removal efficiencies of similar KN, of $69 \%$, with HDT of $100 \mathrm{~h}$ in R1 + R2, which decreased to $55 \%$ when decreasing the HDT to $75 \mathrm{~h}$.

Therefore, with the reduction of HDT it may decrease KN removals confirming those mechanisms of sedimentation and interception in the sludge blanket are associated with the decrease of the Norg concentration, and consequently of $\mathrm{KN}$, in the effluent from the two-stage UASB reactors. OLIVEIRA et al. (1997), DENG et al. (2008) and OLIVEIRA \& SANTANA (2011) also assigned part of the removal of $\mathrm{KN}$ to the formation of struvite $\left(\mathrm{MgNH}_{4} \mathrm{PO}_{4} \cdot 6 \mathrm{H}_{2} \mathrm{O}\right)$ from Nam, phosphate and magnesium.

After the SBR, the average concentrations of Nam still remained similar to those of the affluent, ranging from 153 to $248 \mathrm{mg} \mathrm{L}^{-1}$ (Table 6). In assays 1 and 3 (with HDT of $180 \mathrm{~h}$ ) an increase in the concentration of Nam in the effluent of the SBR occurred due to the ammonification of the Norg and low nitrification (Table 7). 
TABLE 6. Average values and coefficients of variation (cv) of the concentrations of Kjeldahl nitrogen $(\mathrm{KN})$, ammonia nitrogen (Nam.) and organic nitrogen (Norg.), in the affluent and effluent, and of the removal efficiencies of $\mathrm{KN}$ and Norg obtained during the operation of the two-stage UASB reactors (R1 and R2) and the sequential batch reactor fed constinuously (SBR) of the sets I and II, in the assays 1 to 3.

\begin{tabular}{|c|c|c|c|c|c|c|c|c|c|c|c|c|c|}
\hline \multirow{3}{*}{ Assay } & \multirow{3}{*}{ Set } & \multirow{3}{*}{ Sample } & \multirow{3}{*}{$\begin{array}{c}\mathrm{HDT}^{1} \\
\text { (h) }\end{array}$} & \multicolumn{4}{|c|}{ Attribute } & & & \multicolumn{4}{|c|}{ Removal eff. (\%) } \\
\hline & & & & \multicolumn{2}{|c|}{$\mathrm{KN}^{2}$} & \multicolumn{2}{|c|}{$\mathrm{Nam}^{2}{ }^{2}$} & \multicolumn{2}{|c|}{ Norg. $^{2}$} & \multicolumn{2}{|c|}{ KN } & \multicolumn{2}{|c|}{ Norg. } \\
\hline & & & & $\mathrm{A}^{1}$ & $\mathrm{cv}^{2}$ & & $v^{2}$ & $\mathrm{~A}^{1}$ & $\mathrm{cv}^{2}$ & $\mathrm{~A}^{1}$ & $\mathrm{cv}^{2}$ & $\mathrm{~A}^{1}$ & $\mathrm{cv}^{2}$ \\
\hline \multirow{10}{*}{1} & \multirow{4}{*}{ I } & Affl. & --- & 733 & 60 & 188 & 22 & 546 & 79 & --- & --- & --- & -- \\
\hline & & $\mathrm{R} 1$ & 72 & 286 & 11 & 245 & 10 & 41 & 85 & 53 & 32 & 88 & 12 \\
\hline & & $\mathrm{R} 2$ & 28 & 237 & 18 & 223 & 13 & 14 & 105 & $-(3)-$ & --- & 54 & 0 \\
\hline & & $\mathrm{R} 1+\mathrm{R} 2$ & 100 & --- & --- & --- & --- & --- & --- & 61 & 27 & 98 & 3 \\
\hline & \multirow{6}{*}{ II } & Affl. & --- & 798 & 77 & 178 & 22 & 621 & 97 & --- & --- & --- & -- \\
\hline & & $\mathrm{R} 1$ & 72 & 304 & 25 & 235 & 13 & 70 & 79 & 69 & 30 & 91 & 8 \\
\hline & & $\mathrm{R} 2$ & 15 & 301 & 11 & 237 & 11 & 64 & 86 & 14 & 113 & 41 & 70 \\
\hline & & $\mathrm{R} 1+\mathrm{R} 2$ & 87 & --- & --- & --- & --- & --- & --- & 62 & 61 & 78 & 49 \\
\hline & & SBR & 240 & 283 & 14 & 248 & 7 & 35 & 103 & 7 & 118 & 73 & 36 \\
\hline & & $\mathrm{R} 1+\mathrm{R} 2+\mathrm{SBR}$ & --- & --- & --- & --- & --- & --- & --- & 71 & 8 & 97 & 4 \\
\hline \multirow{12}{*}{2} & \multirow{4}{*}{ I } & Affl. & --- & 955 & 58 & 223 & 29 & 732 & 73 & --- & --- & --- & -- \\
\hline & & $\mathrm{R} 1$ & 54 & 288 & 29 & 229 & 26 & 59 & 57 & 67 & 30 & 85 & 21 \\
\hline & & $\mathrm{R} 2$ & 21 & 267 & 32 & 204 & 40 & 63 & 80 & 33 & 103 & 53 & 51 \\
\hline & & $\mathrm{R} 1+\mathrm{R} 2$ & 75 & --- & $-x^{-3}$ & --- & --- & --- & --- & 68 & 39 & 83 & 25 \\
\hline & \multirow{8}{*}{ II } & Affl. & --- & 831 & 52 & 239 & 20 & 592 & 70 & --- & --- & --- & -- \\
\hline & & $\mathrm{R} 1$ & 54 & 264 & 40 & 220 & 37 & 43 & 90 & 63 & 33 & 88 & 16 \\
\hline & & R2 & 11 & 283 & 27 & 246 & 27 & 37 & 80 & 8 & 96 & 33 & 75 \\
\hline & & $\mathrm{R} 1+\mathrm{R} 2$ & 65 & --- & --- & --- & --- & --- & -- & 61 & 30 & 89 & 14 \\
\hline & & \multirow{2}{*}{ SBR } & 240 & 172 & 17 & 153 & 22 & 19 & 59 & 26 & 73 & 51 & 80 \\
\hline & & & 180 & 263 & 37 & 227 & 40 & 36 & 69 & 24 & 94 & (3) & -- \\
\hline & & \multirow{2}{*}{$\begin{array}{c}\mathrm{R} 1+\mathrm{R} 2+ \\
\mathrm{SBR}\end{array}$} & 240 & --- & --- & --- & --- & --- & -- & 66 & 64 & 85 & 17 \\
\hline & & & 180 & --- & --- & --- & --- & --- & --- & 63 & 37 & 91 & 11 \\
\hline \multirow{12}{*}{3} & \multirow{4}{*}{ I } & Affl. & --- & 1161 & 56 & 198 & 48 & 963 & 62 & --- & --- & --- & --- \\
\hline & & $\mathrm{R} 1$ & 42 & 313 & 33 & 225 & 56 & 88 & 83 & 68 & 24 & 87 & 15 \\
\hline & & $\mathrm{R} 2$ & 16 & 290 & 45 & 207 & 63 & 83 & 106 & 18 & 120 & 56 & 63 \\
\hline & & $\mathrm{R} 1+\mathrm{R} 2$ & 58 & --- & --- & --- & --- & --- & --- & 63 & 39 & 86 & 18 \\
\hline & \multirow{8}{*}{ II } & Affl. & --- & 800 & 70 & 199 & 57 & 601 & 79 & --- & --- & --- & -- \\
\hline & & $\mathrm{R} 1$ & 42 & 311 & 42 & 238 & 57 & 73 & 85 & 59 & 32 & 80 & 30 \\
\hline & & R2 & 9 & 285 & 48 & 223 & 63 & 61 & 101 & 22 & 149 & 39 & 91 \\
\hline & & $\mathrm{R} 1+\mathrm{R} 2$ & 51 & --- & --- & --- & --- & --- & --- & 58 & 39 & 80 & 33 \\
\hline & & \multirow{2}{*}{ SBR } & 240 & 272 & 36 & 212 & 57 & 60 & 93 & 25 & 72 & (3) & --- \\
\hline & & & 180 & 259 & 21 & 242 & 22 & 17 & 37 & 28 & 41 & 49 & 55 \\
\hline & & \multirow{2}{*}{$\begin{array}{c}\mathrm{R} 1+\mathrm{R} 2+ \\
\mathrm{SBR}\end{array}$} & 240 & --- & - & -- & --- & -- & --- & 57 & 40 & 82 & 19 \\
\hline & & & 180 & --- & --- & --- & --- & --- & --- & 73 & 27 & 86 & 17 \\
\hline
\end{tabular}

${ }^{1}$ HDT: hydraulic detention time, A: average ${ }^{2}$ Units : KN, Nam., Norg.: $\mathrm{mg} \mathrm{L}^{-1}$ of $\mathrm{N} .{ }^{3}$ No removal or below $1 \%$.

The volumes of injected air were not enough to provide dissolved oxygen in to meet the demands for the oxidation of the remaining organic matter and also for the nitrification, even with low VOL and organic load in the sludge in the SBR, from 0.054 to $0.081 \mathrm{~g}$ total COD (L d $)^{-1}$ and from 0.012 to $0.025 \mathrm{~g}$ total COD ( $\mathrm{g}$ VS sludge $\mathrm{d})^{-1}$, respectively. METCALF \& EDDY (2003) recommend higher values, VOL from 0.1 to $0.3 \mathrm{BOD}_{5,20}(\mathrm{~L} \mathrm{~d})^{-1}$ and ratio $\mathrm{F} / \mathrm{M}$ from 0.04 to $0.10 \mathrm{~g}$ BOD $_{5,20}(\mathrm{~g} \text { VSS sludge d) })^{-1}$, to the SBR with BOD removal and nitrification. In assay 3 (with HDT of $180 \mathrm{~h}$ ) as the aeration time was longer, there were nitrite and nitrate concentrations in the effluent slightly higher than in assay 1 . 
It is removed $7.07 \mathrm{~g}$ of $\mathrm{CaCO}_{3}$ to every $1.00 \mathrm{~g}$ of Nam converted into nitrate (METCALF \& EDDY, 2003). Therefore, the total alkalinity in the effluent from R2 (Table 3) was sufficient to convert 170,142 and $173 \mathrm{mg} \mathrm{L}^{-1}$ of Nam into nitrate in assays 1,2 and 3, respectively. However, the highest values of reduction of Nam concentration, 93 and $19 \mathrm{mg} \mathrm{L}^{-1}$, which occurred due to the nitrification, were observed in assay 2 with HDT of 240 and $180 \mathrm{~h}$ in the SBR (Table 6), respectively. In assay 2 , the aerobic reaction time was longer $(10 \mathrm{~h})$ and also the volume of injected air (Table 2); moreover, with lower average air temperature and lower temperature range over the days, the average value of DO reached to a maximum of $1.4 \mathrm{mg} \mathrm{L}^{-1}$ of $\mathrm{O}_{2}$ (Table 7).

Accordingly, it was observed in the second assay the highest concentration of $\mathrm{N}_{\text {nitric }}\left(\mathrm{N}_{-} \mathrm{NO}_{2}{ }^{-}\right.$ $+\mathrm{N}-\mathrm{NO}_{3}{ }^{-}$), $50.1 \mathrm{mg} \mathrm{L}^{-1}$ (Table 7) in the effluent of the SBR (with HDT of $240 \mathrm{~h}$ ) and the highest intake of TA, of $285 \mathrm{mg} \mathrm{L}^{-1}$ of $\mathrm{CaCO}_{3}$ (Table 3). There was an accumulation of $\mathrm{N}^{-\mathrm{NO}_{2}}{ }^{-}$with a concentration of $46.2 \mathrm{mg} \mathrm{L}^{-1}$, due to some limitation of the activity of the nitrite-oxidizing bacteria. PARK et al. (2010) reported that ammonium-oxidizing bacteria and nitrite-oxidizing bacteria relate both synergistic and competitively since they compete for the same electron acceptor $\left(\mathrm{O}_{2}\right)$. Bacteria of the first group have some advantage in DO limiting conditions causing the accumulation of nitrite

The portion of $42.9 \mathrm{mg} \mathrm{L}$ of Nam removed $\left(93.0 \mathrm{mg} \mathrm{L}^{-1}\right.$ of Nam removed less $50.1 \mathrm{mg} \mathrm{L}^{-1}$ of $\mathrm{N}$ nitric) and which was not nitrified during assay 2 (with HDT of $240 \mathrm{~h}$ ), must have had part of it immobilized in the sludge because there was an increase of the VS mass of the sludge from the $\mathrm{SBR}$. The remainder might have been volatilized, considering that the $\mathrm{pH}$ value increased to above 7.0 in the effluent from the SBR (Table 3), a condition in which there is already $\mathrm{NH}_{3}$, and still presented greater turbulence due to the 10-hour aeration. Also, the low removals of Nam and TN (Table 7) occurred in assays 1 and 3 can be attributed to the immobilization in the sludge and the volatilization of $\mathrm{NH}_{3}$ in the SBR.

TABLE 7. Average values and coefficients of variation (cv) of the effluent concentrations of nitrate $\left(\mathrm{N}-\mathrm{NO}_{3}{ }^{-}\right)$, nitrite $\left(\mathrm{N}_{-} \mathrm{NO}_{2}{ }^{-}\right)$, total nitrogen $(\mathrm{TN})$ and dissolved oxygen (DO), and of the effluent temperature $(\mathrm{T})$ in the sequential batch reactor fed constinuously (SBR) and of the removal efficiencies of Nam and TN in the SBR, in the assays 1 to 3, with HDT of 240 and $180 \mathrm{~h}$.

\begin{tabular}{|c|c|c|c|c|c|c|c|c|c|c|c|c|c|c|c|}
\hline \multirow{3}{*}{ Assay } & \multirow{3}{*}{$\begin{array}{l}\mathrm{HDT}^{1} \\
\text { (h) }\end{array}$} & \multicolumn{10}{|c|}{ Attribute } & \multicolumn{4}{|c|}{ Removal efficiency (\%) } \\
\hline & & \multicolumn{2}{|c|}{$* \mathrm{~N}-\mathrm{NO}_{2}{ }^{-}$} & \multicolumn{2}{|c|}{$* \mathrm{~N}-\mathrm{NO}_{3}{ }^{-}$} & \multicolumn{2}{|c|}{$* \mathrm{TN}$} & \multicolumn{2}{|c|}{$* \mathrm{DO}$} & \multicolumn{2}{|c|}{$\mathrm{T}\left({ }^{\circ} \mathrm{C}\right)$} & \multicolumn{2}{|c|}{ Nam. } & \multicolumn{2}{|c|}{ TN } \\
\hline & & $\mathrm{A}^{1}$ & $\mathrm{cV}$ & $\mathrm{A}^{1}$ & $\mathrm{cV}$ & $\mathrm{A}^{1}$ & $\mathrm{cV}$ & $\mathrm{A}^{1}$ & $\mathrm{Cv}$ & $\mathrm{A}^{1}$ & $\mathrm{cV}$ & $\mathrm{A}^{1}$ & $\mathrm{cV}$ & $\mathrm{A}^{1}$ & $\mathrm{cv}$ \\
\hline 1 & 240 & 0.9 & 4 & 5.2 & 26 & 314 & 23 & 1.2 & 41 & 26.8 & 7 & 5 & 49 & 22 & 62 \\
\hline \multirow{2}{*}{2} & 240 & 46.2 & 7 & 3.9 & 61 & 222 & 13 & 1.4 & 76 & 31.0 & 7 & 24 & 95 & 14 & 128 \\
\hline & 180 & 17.8 & 95 & 2.3 & 43 & 283 & 34 & 1.1 & 72 & 23.8 & 13 & 31 & 72 & 24 & 82 \\
\hline \multirow{2}{*}{3} & 240 & 5.2 & 134 & 3.8 & 42 & 281 & 34 & 0.8 & 67 & 29.7 & 6 & 33 & 64 & 23 & 53 \\
\hline & 180 & 6.6 & 178 & 5.1 & 17 & 270 & 19 & 0.9 & 46 & 28.9 & 7 & 25 & 52 & 25 & 52 \\
\hline
\end{tabular}

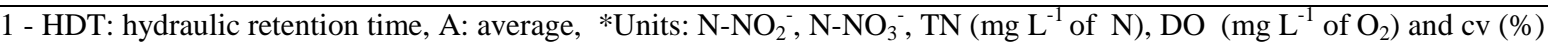

Therefore, the operating conditions adopted in the SBR were not efficient for the marked reduction of the concentration de Nam in the effluent via nitrification. The increased volume of injected air and the improvement of oxygen transfer to the liquid phase, changing the coarse bubble diffusers for fine bubble diffusers, could improve the results. The minimum concentration within the liquid to keep the aerobic environment for the microorganisms depends on several factors: size of the flake, mixing intensity, temperature and especially the rate of oxygen consumption. The sufficient DO concentration in order to occur nitrification without inhibition is $2 \mathrm{mg} \mathrm{L}^{-1}$ of $\mathrm{O}_{2}$, according to VAN HAANDEL \& MARAIS (1999) METCALF \& EDDY (2003) and WEF \& ASCE (2005); a value that was not reached in any of the assays and condition that must have been limiting to obtain higher rates of nitrification in the SBR.

In the treatment system $(\mathrm{R} 1+\mathrm{R} 2+\mathrm{SBR})$ the average values of removal efficiencies of $\mathrm{KN}$ 
ranged from 57 to $73 \%$ and the highest decreases of $\mathrm{KN}$ concentration occurred in the two-stage UASB reactors (Table 6). Similar behavior was verified by OLIVEIRA et al. (2008) and the removals of $\mathrm{KN}$ reached $78 \%$. With strong assistance from the SBR, OLIVEIRA \& SANTANA (2011) reached higher values in the range of 70 to $90 \%$, confirming that the operating conditions of the SBR can be further optimized for the removal of the $\mathrm{KN}$ of the final effluent.

The average concentrations of Ptotal in the affluent were high and ranged from 442 to $887 \mathrm{mg}$ $\mathrm{L}^{-1}$ (Table 8). The removal efficiencies in the anaerobic treatment system, sets I and II, ranged from 58 to $64 \%$ (Table 8) and had a higher contribution from the UASB reactor from the first stage, which was also observed in other studies with two-stage anaerobic reactors (ABREU \& OLIVEIRA NETO, 2009; DUDA \& OLIVEIRA, 2009 and 2011, OLIVEIRA \& SANTANA, 2011). The removal efficiencies of Ptotal followed the variations of TSS removals, indicating that physical removal was the most important process in the reduction of the Ptotal concentrations. However, as done by OLIVEIRA et al. (1997), DENG et al. (2008), OLIVEIRA \& SANTANA (2011), the removal of phosphorus should be attributed not only to the sedimentation of suspended solids but also to the precipitation with aluminum, calcium, iron or magnesium and to the phosphine formation under anaerobic conditions.

In the SBR, the maximum removals of Ptotal, 58 and $51 \%$ (Table 8), occurred in assay 3, when the average air temperature was the highest $\left(24.5^{\circ} \mathrm{C}\right)$. These average values are found in the range of the highest removal efficiencies of Ptotal, from 45 to $66 \%$, obtained by OLIVEIRA et al. (2008) and OLIVEIRA \& SANTANA (2011) in SBR treating anaerobic effluent, which were also higher when the average air temperature was the highest, from 23.7 to $24.5{ }^{\circ} \mathrm{C}$.

The research results on the effect of the temperature on the biological phosphorus removal were contradictory. Thus, it is concluded that the process is practically indifferent to temperature changes when compared to other biological processes (WEF \& ASCE, 2005). However, the temperature has a marked effect on the sedimentation characteristics of biological solids (METCALF \& EDDY, 2003). As the temperature increases, the viscosity and the density of the liquid in the reactor decrease and the solids settle faster (WEF \& ASCE, 1998b). Thus, increasing the temperature may have caused a more intense biological sedimentation of immobilized $\mathrm{P}$, which may be confirmed by the higher removal efficiencies of VSS in the SBR, of 73 and 64\% (Table 5), in the assay 3.

PEREIRA-RAMIREZ et al. (2003) obtained a lower removal of Ptotal, only $26 \%$ in biological reactor with continuous aeration with HDT of $4 \mathrm{~d}$, fed with effluent of the system with UASB reactor and anaerobic filter treating swine wastewater. Thus, with the SBR as it has been operated in this work and by OLIVEIRA et al. (2008) and OLIVEIRA \& SANTANA (2011), it is possible to obtain higher removals of Ptotal, with less energy use, considering that the aeration in the SBR was intermittent.

In the treatment system $(\mathrm{R} 1+\mathrm{R} 2+\mathrm{SBR})$, the average values of the removal efficiencies of Ptotal ranged from 61 to $82 \%$ (Table 8 ) and were higher in the two-stage UASB reactors. Only in the assays 2 and 3 there was the contribution of the SBR to the reduction of the average values of the Ptotal concentration in the final effluent and their coefficients of variation. These Ptotal removal values were similar to those obtained by DENG et al. (2008), from 49 to $71 \%$, OLIVEIRA et al. (2008), from 74 to $83 \%$, and OLIVEIRA \& SANTANA (2011), from 57 to $74 \%$, who also used the SBR fed with the effluent of the UASB reactors treating swine wastewater.

Affluent concentrations of coliforms were high, with average values of total coliforms that ranged from $1.6 \times 10^{6}$ to $2.6 \times 10^{7} \mathrm{MPN}(100 \mathrm{~mL})^{-1}$ and thermotolerant coliforms from $1.5 \times 10^{6}$ to $2.5 \times 10^{7} \mathrm{MPN}(100 \mathrm{~mL})^{-1}$ (Table 8). In the R1 effluent, the total coliform count decreased and was lower in set II, in assay 3, with average of $7.9 \times 10^{5} \mathrm{MPN}(100 \mathrm{~mL})^{-1}$. In the R2 effluent it continued to decrease, reaching the lowest value of $2.7 \times 10^{5} \mathrm{MPN}(100 \mathrm{~mL})^{-1}$ in assays 1 and 3 , in the sets I and II. 
TABLE 8. Average values and coefficients of variation (cv) of the total coliforms (TC) and thermotolerant coliforms $(\mathrm{TeC})$ and of total phosphorus (Ptotal), and their removal efficiencies (E) obtained during the operation of two-stage UASB reactors (R1 and R2) and the sequential batch reactor fed constinuously (SBR) of the sets I and II, in the assays 1 to 3 .

\begin{tabular}{|c|c|c|c|c|c|c|c|c|c|c|c|}
\hline \multirow{3}{*}{ Assay } & \multirow{3}{*}{ Set } & \multirow{3}{*}{ Sample } & \multirow{3}{*}{$\begin{array}{c}\mathrm{HDT}^{1} \\
(\mathrm{~h})\end{array}$} & \multirow{2}{*}{\multicolumn{4}{|c|}{ Colimetry }} & \multicolumn{4}{|c|}{ Ptotal } \\
\hline & & & & & & & & \multicolumn{2}{|c|}{$\left(\mathrm{mg} \mathrm{L}^{-1}\right)$} & \multicolumn{2}{|c|}{$E^{2}$} \\
\hline & & & & $\mathrm{TC}^{2}$ & $E^{2}$ & $\mathrm{TeC}^{2}$ & $E^{2}$ & $\mathrm{~A}^{1}$ & $\mathrm{cv}^{2}$ & $\mathrm{~A}^{1}$ & $\mathrm{cv}^{2}$ \\
\hline \multirow{10}{*}{1} & \multirow{4}{*}{ I } & Affl. & --- & $6.210^{6}$ & --- & $6.210^{6}$ & --- & 781 & 39 & --- & --- \\
\hline & & $\mathrm{R} 1$ & 72 & $1.710^{6}$ & 62.7 & $1.710^{6}$ & 62.7 & 303 & 21 & 58 & 19 \\
\hline & & $\mathrm{R} 2$ & 28 & $2.710^{5}$ & 66.1 & $2.710^{5}$ & 66.1 & 287 & 19 & 14 & 83 \\
\hline & & $\mathrm{R} 1+\mathrm{R} 2$ & 100 & --- & 87.3 & --- & 87.3 & --- & --- & 59 & 23 \\
\hline & \multirow{6}{*}{ II } & Affl. & --- & $2.810^{6}$ & --- & $2.810^{6}$ & --- & 552 & 51 & --- & --- \\
\hline & & $\mathrm{R} 1$ & 72 & $2.410^{6}$ & 85.7 & $1.310^{6}$ & 53.6 & 236 & 45 & 54 & 29 \\
\hline & & $\mathrm{R} 2$ & 15 & $1.210^{6}$ & 50.0 & $1.210^{6}$ & 7.7 & 204 & 31 & 16 & 79 \\
\hline & & $\mathrm{R} 1+\mathrm{R} 2$ & 87 & --- & 57.1 & --- & 57.1 & --- & --- & 59 & 21 \\
\hline & & SBR & 240 & $2.310^{5}$ & 80.8 & $2.310^{5}$ & 80.8 & 200 & 19 & 13 & 147 \\
\hline & & $\mathrm{R} 1+\mathrm{R} 2+\mathrm{SBR}$ & --- & --- & 91.8 & --- & 91.8 & --- & --- & 61 & 16 \\
\hline \multirow{12}{*}{2} & \multirow{4}{*}{ I } & Affl. & --- & $2.610^{7}$ & --- & $2.510^{7}$ & --- & 478 & 55 & --- & --- \\
\hline & & $\mathrm{R} 1$ & 54 & $1.910^{6}$ & 85.6 & $1.810^{6}$ & 78.5 & 165 & 40 & 61 & 33 \\
\hline & & R2 & 21 & $1.210^{6}$ & 41.6 & $1.210^{6}$ & 36.9 & 155 & 39 & 30 & 77 \\
\hline & & $\mathrm{R} 1+\mathrm{R} 2$ & 75 & --- & 92.4 & --- & 88.6 & --- & --- & 64 & 26 \\
\hline & \multirow{8}{*}{ II } & Affl. & --- & $3.310^{6}$ & --- & $3.310^{6}$ & --- & 442 & 62 & --- & --- \\
\hline & & $\mathrm{R} 1$ & 54 & $1.210^{6}$ & 67.3 & $9.410^{5}$ & 73.8 & 164 & 52 & 60 & 38 \\
\hline & & $\mathrm{R} 2$ & 11 & $3.310^{5}$ & 59.7 & $2.810^{5}$ & 67.7 & 155 & 62 & 36 & 67 \\
\hline & & $\mathrm{R} 1+\mathrm{R} 2$ & 65 & --- & 77.9 & --- & 89.5 & $\begin{array}{ll}-- \\
\end{array}$ & --- & 60 & 38 \\
\hline & & \multirow{2}{*}{ SBR } & 240 & --- & --- & --- & --- & 89 & 34 & 27 & 74 \\
\hline & & & 180 & $5.410^{4}$ & 90.4 & $2.010^{4}$ & 91.9 & 132 & 35 & 31 & 78 \\
\hline & & \multirow{2}{*}{$\mathrm{R} 1+\mathrm{R} 2+\mathrm{SBR}$} & 240 & --- & --- & --- & --- & $\begin{array}{l}-- \\
\end{array}$ & --- & 74 & 67 \\
\hline & & & 180 & --- & 98.1 & --- & 99.3 & --- & --- & 70 & 22 \\
\hline \multirow{12}{*}{3} & \multirow{4}{*}{ I } & Affl. & --- & $5.910^{6}$ & --- & $1.510^{6}$ & --- & 767 & 67 & --- & --- \\
\hline & & $\mathrm{R} 1$ & 42 & $5.710^{6}$ & 3.4 & $5.610^{5}$ & 62.7 & 294 & 48 & 58 & 30 \\
\hline & & $\mathrm{R} 2$ & 16 & $1.210^{6}$ & 78.9 & $1.910^{5}$ & 66.1 & 275 & 41 & 13 & 83 \\
\hline & & $\mathrm{R} 1+\mathrm{R} 2$ & 58 & --- & 79.6 & --- & 87.3 & --- & --- & 58 & 33 \\
\hline & \multirow{8}{*}{ II } & Affl. & --- & $1.610^{6}$ & --- & $1.610^{6}$ & --- & 887 & 83 & -- & --- \\
\hline & & $\mathrm{R} 1$ & 42 & $7.910^{5}$ & 52.2 & $7.910^{5}$ & 52.2 & 414 & 65 & 54 & 33 \\
\hline & & $\mathrm{R} 2$ & 9 & $2.710^{5}$ & 65.3 & $2.510^{5}$ & 68.4 & 327 & 67 & 31 & 86 \\
\hline & & $\mathrm{R} 1+\mathrm{R} 2$ & 51 & --- & 83.4 & --- & 84.9 & $\begin{array}{ll}--- \\
\end{array}$ & --- & 61 & 34 \\
\hline & & \multirow{2}{*}{ SBR } & 240 & --- & --- & --- & --- & 154 & 35 & 58 & 34 \\
\hline & & & 180 & $4.610^{4}$ & 83.4 & $3.110^{4}$ & 87.9 & 163 & 25 & 51 & 29 \\
\hline & & \multirow{2}{*}{$\mathrm{R} 1+\mathrm{R} 2+\mathrm{SBR}$} & 240 & --- & --- & --- & --- & --- & 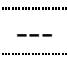 & 82 & 12 \\
\hline & & & 180 & --- & 97.2 & --- & 98.2 & --- & -- & 79 & 53 \\
\hline
\end{tabular}

${ }^{1}$ HDT: hydraulic detention time, E: removal efficiency. A: average, ${ }^{2}$ Units: TC and TeC: most probable number per $100 \mathrm{~mL}(\mathrm{MPN}$ $\left.(100 \mathrm{~mL})^{-1}\right), \mathrm{E}(\%), \mathrm{c} \mathrm{v}(\%)$

In assay 2, with HDT of $75 \mathrm{~h}$ in the anaerobic treatment system (R1 + R2) of the set I and with VOL of $9.4 \mathrm{~g}$ total COD $(\mathrm{L} \mathrm{d})^{-1}$ in $\mathrm{R} 1$, the highest removal efficiency of total coliforms was observed, of $92.4 \%$. For thermotolerant coliforms the largest removal, of $89.5 \%$, occurred in the same assay, but in set II, with HDT of $65 \mathrm{~h}$ in R1 + R2.

The lowest concentration of thermotolerant coliforms of $2.0 \times 10^{4} \mathrm{NMP}(100 \mathrm{~mL})^{-1}$ was reached in the effluent from the SBR in the assay 2 with HDT of $180 \mathrm{~h}$, when the removal 
efficiencies in the SBR and in the treatment system $(\mathrm{R} 1+\mathrm{R} 2+\mathrm{SBR})$ showed the highest values, of 91.9 and $99.3 \%$, respectively. OLIVEIRA et al. (2008) and OLIVEIRA \& SANTANA(2011) obtained better results in two-stage UASB reactors followed by the SBR for the treatment of swine wastewater, even with the highest counts of thermotolerant coliforms in the affluent, from $1.5 \times 10^{7}$ to $4.6 \times 10^{8} \mathrm{NMP}(100 \mathrm{~mL})^{-1}$. The authors achieved removals of up to $99.999 \%$ and minimum concentrations of thermotolerant coliforms, of $2.0 \times 10^{3} ; 2.4 \times 10^{3} ; 9.3 \times 10^{3}$ and $9.3 \times 10^{3} \mathrm{MPN}$ $(100 \mathrm{~mL})^{-1}$, in effluent of the SBR with HDT of $240,160,56$ and $28 \mathrm{~h}$, respectively.

PEREIRA-RAMIREZ et al. (2003) were able to obtain even lower levels of thermotolerant coliforms, of $1.8 \times 10^{3} \mathrm{MPN}(100 \mathrm{~mL})^{-1}$, in the effluent from the biological reactor with continuous aeration operated at HDT of $96 \mathrm{~h}$. Therefore, the highest HDT, 240 and $180 \mathrm{~h}$, used in the SBR in assays 1, 2 and 3 did not determine better microbiological quality of the effluent, indicating that the frequency and the greater proportion of the aerobic reaction step in the SBR cycle may be more effective for coliform removal, as observed by OLIVEIRA \& SANTANA (2011) and PEREIRARAMIREZ et al. (2003).

The inclusion of the SBR was important to significantly increase the removal of thermotolerant coliforms and reach values under $10^{5} \mathrm{MPN}(100 \mathrm{~mL})^{-1}$ in the final effluent, so that its use is allowed in the irrigation of larger cultivations through drip irrigation, according to the guidelines for reuse of the World Health Organization (WHO, 2006).

\section{CONCLUSIONS}

The highest volumetric production of methane, total COD, CODdiss, TSS, VSS, KN, Norg and Ptotal removals occurred in the UASB reactor of the first stage.

The inclusion of the UASB reactor of the second stage contributes to the effluent quality improvement and the increase of the volumetric production of methane, with greater stability of the two-stage anaerobic treatment system. Consequently, increases occur in the removal efficiencies of total COD, CODdiss, TSS, VSS, Ptotal, total coliforms and thermotolerant coliforms.

In the two-stage anaerobic treatment system the various volumes of the UASB reactor of the second stage and the HDT and VOL values used, do not cause great differences in total COD, TSS, VSS, KN, Norg and Ptotal removals. This allows it to halve the volume of the two-stage UASB reactors and to maintain high removal efficiencies of total COD, TSS and VSS in the range of 91 to $94 \%$, and $\mathrm{KN}$ and Ptotal, around 60\%. Also, the shortest HDT, increasing the VOL, promotes increases in the CODdiss and in the volumetric production of methane.

The post-treatment of the anaerobic effluent in the SBR improves the quality of the final effluent by means of marked decreases in the values of total COD, CODdiss, TSS, VSS, Ptotal, total coliforms and thermotolerant coliforms and increases the stability of the treatment system. The largest increases are in the removal efficiencies for the total coliforms and the thermotolerant coliforms, which typically have lower reduction of concentration in the anaerobic treatment system.

\section{ACKNOWLEDGMENTS:}

To CNPq for the financial support for the research and to CAPES for the doctoral scholarship granted to the first author.

\section{REFERENCES}

ABREU NETO, M.S.; OLIVEIRA, R.A. de. Remoção de matéria orgânica, de nutrientes e de coliformes no processo anaeróbio em dois estágios (reator compartimentado seguido de reator UASB) para o tratamento de águas residuárias de suinocultura. Engenharia Agrícola, Jaboticabal, v. 29, n.1, p.148-161, jan/mar, 2009.

APHA; AWWA; WEF. Standard methods for the examination of water and wastewater. $21^{\text {st. }}$ ed. Washington, 2005. 
BERNET, N.; DELGENES, N.; AKUNNA, J.C.; DELGENES, J.P. Combined anaerobic-aerobic SBR for the treatment of piggery wastewater. Water Research, London, v.34, n.2, p.611-619, 2000.

BICHUETTE, A.A.; DUDA, R, M.; OLIVEIRA, R.A. de. Treatment of swine wastewater in a twostage upflow anaerobic sludge blanket reactors. In: LATIN AMERICAN WORKSHOP AND SYMPOSIUM ON ANAEROBIC DIGESTION, 9. 2008, Isla de Pascua - Proceedings...Isla de Pascua: International Water Association, 2008. CD-ROM.6p.

BRASIL. Resolução $n^{\circ}$ 357, de 17 de março de 2005. Dispõe sobre classificação dos corpos de água e diretrizes ambientais para o seu enquadramento, bem como estabelece as condições e padrões de lançamento de efluentes e dá outras providências.Diário Oficial [da] República Federativa do Brasil, Poder legislativo, Brasília-DF, 18 mar. Seção 1, p.58.

CHERNICHARO, C.A.L. de. Post-treatment options for the anaerobic treatment of domestic wastewater. Reviews in Environmental Science and Bio/Technology, Dordrecht, v.5, p. 73-92, 2006.

CHERNICHARO, C.A.L. de. Reatores anaeróbios: princípios do tratamento biológico de águas residuárias. 2.ed. Belo Horizonte: Departamento de Engenharia Sanitária e Ambiental Universidade Federal de Minas Gerais, 2007. 379p.

DENG, L.; ZHENG, P.; CHEN, Z.; MAHMOOD, Q. Improvement in post-treatment of digested swine wastewater. Bioresource Technology, Barking, v.99, n.8 , p.3136-3145, 2008.

DILALLO, R.; ALBERTSON, O. E. Volatile acids by direct titration. Journal Water Pollution Control Federation,Alexandria, v.33, n.4, p.356-365, 1961.

DUDA, R, M.; FACHINNI, A.A.; OLIVEIRA, R.A. de Tratamento de águas residuárias de suinocultura em reatores UASB em dois estágios seguidos de reator sequencial em batelada aeróbio In: CONGRESSO BRASILEIRO DE ENGENHARIA SANITÁRIA E AMBIENTAL, 25, 2009, Recife. Anais...Rio de Janeiro: Associação Brasileira de Engenharia Sanitária e Ambiental, 2009. CD-ROM. 11p.

DUDA, R, M.; OLIVEIRA, R.A. de. Reatores anaeróbios operados em batelada sequencial, seguidos de lagoas de polimento, para o tratamento de águas residuárias de suinocultura. Parte II: remoção de nutrientes e coliformes. Engenharia Agrícola, Jaboticabal, v.29, n.1, p.135-147, 2009.

DUDA, R, M.; OLIVEIRA, R.A. de.Tratamento de águas residuárias de suinocultura em reator UASB e filtro anaeróbio em série seguidos de filtro biológico percolador. Engenharia Sanitária e Ambiental, Rio de Janeiro, v.16, n.1, p.91-100, 2011.

FORESTI, E.; ZAIAT, M.; VALLERO, M. Anaerobic processes as the core technology for sustainable domestic wastewater treatment: consolidated applications, new trends, perspectives, and challenges. Reviews in Environmental Science and Bio/Technology, Dordrecht, v.5, p.3-19, 2006.

GERARDI, M.H. The microbiology of anaerobic digesters. New Jersey: Wiley \& Sons, 2003. $130 \mathrm{p}$.

JENKINS, S.R.; MORGAN, J.M.; SAWYER, C.L. Measuring anaerobic sludge digestion and growth by a simple alkalimetric titration. Journal Water Pollution Control Federation, Alexandria, v.55, n.5, p.448-453, 1983.

KUNZ, A.; STEINMETZ, R.L.R.; RAMME, M.A.; COLDEBELLA, A. Effect of storage time on swine manure solid separation efficiency by screening. Bioresource Technology, Barking, v.100, p.1815-1818, 2009. 
METCALF; EDDY. Suspended growth biological treatment process. In: TCHOBANOGLOUS, G.; BURTON, P.L.; STENSEL, H.D. Wastewater engineering: treatment and reuse. 4 ed. New York:McGraw-Hill, 2003. p.659-880.

MIRANDA, C.R. de. Aspectos ambientais da suinocultura brasileira. In: SEGANFREDO, M. A. (Ed.). Gestão ambiental na suinocultura. Brasília-DF: Embrapa Informação Tecnológica, 2007. cap. 1, p. 13-36.

OLIVEIRA R.A. de; VAZOLLER, R.F.; FORESTI, E. Sludge bed characteristics of UASB reactors: growth, activity, microbial structure and chemical composition of granules. In: INTERNATIONAL CONFERENCE ON ANAEROBIC DIGESTION, 8, 1997, Sendai. Proceedings...Sendai: International Association Water Quality, 1997. p.524-531.

OLIVEIRA, R.A. de; DUDA, R, M.; LONGARESI, R. h. Reatores UASB em dois estágios seguidos de reator sequencial em batelada aeróbio para o tratamento de águas residuárias de suinocultura. In: LATIN AMERICAN WORKSHOP AND SYMPOSIUM ON ANAEROBIC DIGESTION, 9, 2008, Isla de Pascua-Chile. Proceedings...Isla de Pascua: International Water Association, 2008. CD-ROM. 6p.

OLIVEIRA, R.A. de, SANTANA, A.M. de. Tratamento de águas residuárias de suinocultura em reatores anaeróbios de fluxo ascendente com manta de lodo (UASB) em dois estágios seguidos de reator operado em batelada seqüencial (RBS). Engenharia Agrícola, Jaboticabal, v.31, n.1, p.178192, 2011.

PARK, S.; BAE, W.; RITTMANN, B. E. Operational boundaries for nitrite accumulation in nitrification based on minimum/maximum substrate concentrations that include effects of oxygen limitation, $\mathrm{pH}$ and free ammonia and free nitrous acid inhibition. Enviromental Science and Technology, Washington, v. 44, p. 335-342, 2010.

PEREIRA-RAMIREZ, O., ANTUNES, R,M., QUADRO, M., KOETZ, P. Remoção da DQO e nitrificação em reator biológico aerado no pós-tratamento de águas residuárias de suinocultura. Revista Brasileira de Agrociência, Pelotas, v.9, n.3, p.279-286, 2003.

RODRIGUES, L.S.; SILVA, I.J.; ZOCRATO, M.C. de O.; PAPA, D.N.; SPERLING, M.V.; OLIVEIRA, P.R. Avaliação de desempenho de reator UASB no tratamento de águas residuárias de suinocultura. Revista Brasileira de Engenharia Agrícola e Ambiental, Campina Grande, v.14, n.1, p.94-100, 2010.

SANTANA, A.M. de; OLIVEIRA, R.A. de. Desempenho de reatores anaeróbios de fluxo ascendente com manta de lodo em dois estágios tratando águas residuárias de suinocultura. Engenharia Agrícola, Jaboticabal, v.25, n.3, p. 817-830, 2005.

SONG, M.; SHIN, S.G.; HWANG, S. Methanogenic population dynamics assessed by real-time quantitative PCR in sludge granule in upflow anaerobic sludge blanked treating swine wastewater. Bioresource Technology, Barking, v.101, p.S23-S28, 2010.

TREVISAN, V.; MONTEGGIA, L.O. Produção de biogás a partir de efluente da suinocultura utilizando digestão anaeróbia em dois estágios. In: SIMPÓSIO INTERNACIONAL SOBRE GERENCIAMENTO DE RESÍDUOS DE ANIMAIS, 1., 2009, Florianópolis. Anais... Concórdia: Embrapa Suínos e Aves, 2009. p.264-268.

UNESP - UNIVERSIDADE ESTADUAL PAULISTA - Faculdade de Ciências Agrárias e Veterinárias. Departamento de Ciências Exatas. Estação Agroclimatológica: valores médios de período de 1971 a 2010. Disponível em <www.fcav.unesp.br/estação〉. Acesso em: fev. 2011. 
VAN HAANDEL, A.C.; MARAIS, G. Remoção biológica de nutrientes. In: VAN HAANDEL, A.C.; MARAIS, G. O comportamento do sistema de lodo ativado: teoria e aplicações para projetos e operação. Campina Grande: Epgraf, 1999, p.99-184.

VON SPERLING, M. Legislação ambiental e impacto do lançamento de efluentes nos corpos receptores. In: Introdução à qualidade das águas e ao tratamento de esgotos: princípios do tratamento biológico de águas residuárias. 3. ed. Belo Horizonte: Departamento de Engenharia Sanitária e Ambiental, Universidade Federal de Minas Gerais, 2005. cap. 3, p. 135-247.

WEF; ASCE. Integrated biological process for nutrient control. In: Design of municipal wastewater treatment plants: liquid treatment processes. $4^{\text {th }} \mathrm{ed}$. Alexandria: Water Environment Federation and American Society of Civil Engineers, 1998a, v. 2, cap. 15, p.1-114.

WEF; ASCE. Dewatering. In: Design of municipal wastewater treatment plants: solids processing and disposal. 4th ed. Alexandria: Water Environment Federation and American Society of Civil Engineers, 1998b, v. 3, cap. 21, p.1-126.

WEF; ASCE. Combined nutrient removal systems. In: Biological nutrient removal (BNR) operation in wastewater treatment plants.Alexandria: Water Environment Federation Press and McGraw-Hill, 2005. p.159-226.

WHO. Guidelines for the safe use of wastewater, excreta and greywater - policy and regulatory aspects. Genebra: World Health Organization, 2006. v. 1, 100 p.

ZHANG, Z.; ZHU, J.; KING, J.; LI, W. Two step-fed SBR for treating swine manure. Process Biochemistry, London, v.41, p.892-900, 2006. 